GROUND-WATER FLOW AND SOLUTE TRAINSPORT AT A

NUNICIPAL LANDFILL SITE ON LONG ISLAND, NEW YORK--

PART 2: SIMULATION OF GROUND-WATER FLOW

by Eliezer J. Wexler and Paul E. Maus

U.S. GEOLOGICAL SURVEY

Water-Resources Investigations

Report 86-4106

Prepared in cooperation with the

TOWN OF BROOKHAVEN

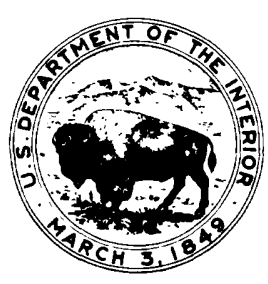

Syosset, New York 


\section{UNITED STATES DEPARTMENT OF THE INTERIOR}

DONALD PAUL HODEL, Secretary

GEOLOGICAL SURVEY

Dallas L. Peck, Di rector

For additional information write to:

U.S. Geological Survey

5 Aerial Way

Syosset, NY 11791

Telephone: (516) 938-8830
Copies of this report may be purchased from:

U.S. Geological Survey Books and Open-File Reports Federal Center, B1dg. 41 Box 25425

Denver, CO 80225

Telephone: (303) 236-7476 


\section{CONTENTS}

Abstract. . . . . . . . . . . . . . . . . . . 1

Introduction. . . . . . . . . . . . . . . . . . . 1

Purpose and scope. . . . . . . . . . . . . . . . . 2

Location of study area... . . . . . . . . . . . . 2

Previous investigations. . . . . . . . . . . . . . 3

Acknowledgments. . . . . . . . . . . . . . . 5

Geohydrology. . . . . . . . . . . . . . . ..... . 5

Lloyd aquifer and Raritan clay . . . . . . . . . . . 6

Magothy aquifer. . . . . . . . . . . . . . . 8

Monmouth greensand . . . . . . . . . . . . . . . 8

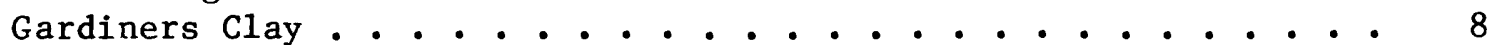

Upper glacial aquifer. . . . . . . . . . . . . . . 10

Ground-water flow system. . . . . . . . . . . . . 12

Recharge ............................. 13

Precipitation and evapotranspiration. . . . . . . . 13

other sources of ground-water recharge. . . . . . . . 14

Discharge. . . . . . . . ............... 15

Seepage to streams. . . .............. 15

Carmans River. .................. 17

Swan River.................... 17

Beaverdam Creek. . . . . . . . . . . . . 17

Yapahank Creek .................. 17

Little Neck Run. . . . . . . . . . . . 17

Motts Brook. ................... 17

other streams................... 17

Pumpage ........................... 18

Ground water in the upper glacial aquifer. . . . . . . . . 18

Water-table altitudes in September 1982 . . . . . . . . 18

Ground water in the Magothy aquifer. . . . . . . . . . . 20

Water budget . . . . . . . . . . . . . . . . . 22

Simulation of ground-water flow . . . . . . . . . . . . . . 24

Theoretical background . . . . . . . . . . . . . . 24

Model design . . . . . . . . . . . . . . . . . . 26

Application of boundary conditions . . . . . . . . . . . 28

Prescribed-head boundaries. . . . . . . . . . . 28

Head-dependent flux boundary. . . . . . . . . . . 28

Prescribed-flux boundaries. . . . . . . . . . . 29

Recharge boundary. . . . . . . . . . . . . 29

Freshwater-saltwater interface . . . . . . . . 29

Aquifer properties . . . . . . . . . . . . . . . . 30

Points of recharge and discharge . . . . . . . . . . . . . 30

Pumpage and redistribution of ground water. . . . . . . 30

Ground-water discharge to streams . . . . . . . . . 30

Model calibration. . . . . . . . . . . . . . . . . 31

Simulated water-table altitudes . . . . . . . . . 32

Simulated water budget. . . . . . . . . . . . . . . 32

Ground-water velocities near the Brookhaven landfill site. . . . . 34

Summary and conclusions . . . . . . . . . . . . . . . . . 37

References cited. . . . . . . . . . . . . . . . . 38 


\section{ILLUSTRATIONS}

Page

Figure 1. Map showing location of study area surrounding Brookhaven landfill sjte................... 3

2. Nlap showing major geographic features of the modeled area - 4

3. Generalized north-south hydrogeologic section through the Town of Brookhaven showing relative positions of principal aquifers and confining units.............. 6

4. Nap showing thickness of confining units (Gardiners Clay and llonmouth greensand) beneath upper glacial aquifer in study area. . . . . . . . . . . . . . . . .

5. Ilap showing configuration of base of upper glacial aquifer in study area ....................

6. Generalized north-south hydrogeologic section of the ground-water system south of the regional ground-water divide showing pattern of ground-water flow . . . . .

7. Five-year hydrographs of four observation wells in study area, 1979-33 . . . . . . . . . . . 20

8. Map showing potentiometric surface of Magothy aquifer in study area, September 1982............. 21

9. Map showing area considered in water-budget analysis. . . 23

10. Diagram showing components and rates of flow in waterbudget area as determined fron water-budget analysis. . . . 24

11. Map showing finite-element grid used to represent the study area. . . . . . . . . . . . . . . . .

12. Map showing simulated and observed (September 1982) watertable configuration . . . . . . . . . . . . .

13. Diagram showing components and rates of flow in waterbudget area as determined by calibrated model . . . . .

14. Plots showing (A) simulated ground-water velocity, and (B) direction of ground-water flow in the upper glacial aquifer downgradient from Brookhaven landfill site. . . 


\section{TABLES}

Table 1. Principal aquifers and confining units underlying Town of

Brookhaven.................... 7

2. Annual, average monthly, and average annual precipitation at Patchogue and Upton ....................

3. Sewage-treatment-plant discharge to ground water in study area, 1981.....................

4. Average base flow at partial- and continuous-record stations in study area................... 16

5. Public-supply and industrial pumpage in study area, 1981 . . 18

6. Stream-stage-measurement sites used in study. . . . . . . 19

7. Initial and final values of hydraulic conductivity used in steady-state flow model ............... 32

8. Simulated inflows to and discharges from study area . . . 34

9. Description of observation wells in study area........ 41

\section{PLATES}

(in pocket)

Plate 1. Map showing locations of all hydrologic data points in study area.

2. Map showing water-table altitude in study area, September 1982. 


\section{CONVERSION FACTORS AND ABBREVIATIONS}

For the convenience of readers who prefer metric (International System) units rather than the inch-pound units used in this report, the following conversion factors may be used:

Multiply Inch-Pound Units

inch (in)
foot ( $t t)$
mile (mi)

acre

square foot $\left(\mathrm{ft} \mathrm{t}^{2}\right)$

square $\mathrm{mile}\left(\mathrm{mi}^{2}\right)$

by

To Obtain Metric Units

Length

25.40

0.3048

1.609

Area

$$
\begin{aligned}
& 0.4047 \\
& 0.09294 \\
& 2.590
\end{aligned}
$$

Volume

gallon (gal)

3.785

Flow

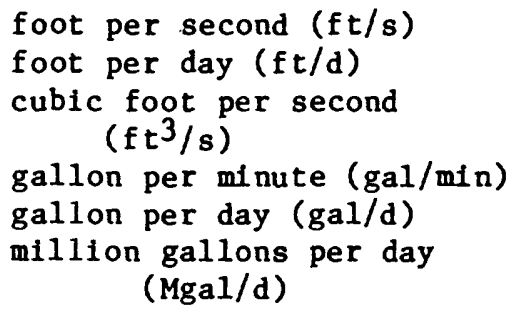

0.3048

0.3048

0.02832

0.06308

0.003785

0.04381 hectare

square meter $\left(\mathrm{m}^{2}\right)$

millimeter (mm)

meter (m)

kilometer ( $\mathrm{km})$ square $\mathrm{kil}$ lometer $\left(\mathrm{km}^{2}\right)$

National Geodetic Vertical Datum of 1929 (NGVD of 1929): A geodetic datum derived from a general adjustment of the firstorder level nets of both the United States and Canada, formerly called "mean sea level." 


\title{
Ground-Water Flow and Solute Transport at a Municipal Landfill Site on Long Island, New York-- Part 2: Simulation of Ground-Water Flow
}

\begin{abstract}
Hydrogeologic data were collected from a 26-square-mile area surrounding a municipal landfill site in the Town of Brookhaven, New York, as part of an investigation of solute transport from the site. These data were used to develop a steady-state ground-water flow model of the upper glacial (water-table) aquifer in the area. The model accounts for leakage through confining units underlying the aquifer, seepage to streams, recharge from precipitation, and pumpage and redistribution of ground water. Refined estimates of aquifer and confining-unit properties were obtained through model calibration.
\end{abstract}

The model was calibrated by matching predicted water-table altitudes to measured water-table altitudes of September 1982, when streamflow and water levels were close to long-term average values. The best match was achieved with a horizontal hydraulic conductivity of 200 feet per day ( $f t / d$ ) for the upper glacial aquifer and a vertical hydraulic conductivity of $7 \times 10^{-3} \mathrm{ft} / \mathrm{d}$ for the confining unit. Flows across the model boundaries, calculated as part of the calibration procedure, compared favorably with estimates obtained from a waterbudget analysis of the area.

Ground-water velocities and probable flow paths in the site vicinity were calculated from water levels generated by the calibrated model. Ground water at the center of the site flows southeastward at $1.1 \mathrm{ft} / \mathrm{d}$.

This report is the second in a three-part series describing the hydrogeologic conditions and ground-water quality, ground-water flow, and solute transport in the landfill site vicinity.

\section{INTRODUCTION}

The Town of Brookhaven, in central Suffolk County, N.Y., operates a sanitary landfill within the 180-acre Brookhaven landfill site in the south-central part of the Town (fig. 1). Disposal of municipal solid waste began in 1974, and by 1983, the sanitary landfill covered 60 acres of the site. The bottom of the sanitary landfill is lined with a polyvinyl chloride (PVC) membrane 0.02 in. thick.

Recent studies have shown that landfill leachate has degraded the quality of ground water near several sanitary landfills on Long Island (Kimmel and Braids, 1980; Padar, 1983). In 1981, the U. S. Geological Survey, in cooperation with the Town of Brookhaven, began a hydrologic investigation of the Brookhaven landfill site and vicinity. The overall objective of the study was to develop a digital solute-transport model that would allow an evaluation 
of solute transport associated with landfill leachate that has entered the underlying aquifer.

The investigation consisted of three phases; results are described in three reports. In the first phase, hydrologic, geologic, and water-quality data were collected within a $4-\mathrm{mi}^{2}$ area centered around the landfill site. Part 1 of this series (Wexler, 1987a) describes that phase of the investigation and delineates the extent of a leachate plume emanating from the sanitary landfill despite the PVC liner.

The second phase of the investigation, described herein (part 2 of the series), entailed the development and calibration of a steady-state ground-water flow model to evaluate the ground-water flow system in the $26-\mathrm{mi}^{2}$ area surrounding the Brookhaven landfill site (fig. 1). The size of the area to be studied was determined by the location of the natural hydrogeologic boundaries closest to the site. The major geographic features of the study area are shown in figure 2 .

The purpose of the modeling effort was twofold. First, development and calibration of the model would yield refined estimates of aquifer and confining-unit properties and of flows across the model boundaries, and second, the calibrated model could be used to determine the rates and direction of ground-water flow downgradient of the site under long-term average hydrologic conditions. These data were used in the third phase of the investigation, which entailed development of a predictive solute-transport mode1, described in part 3 of this series (Wexler, 1987b).

\section{Purpose and Scope}

This report (1) describes the ground-water flow system and presents initial estimates of aquifer and confining-unit properties, rates of groundwater discharge within the study area, and rates of flow across the boundaries of the area; (2) explains the development and calibration of the steady-state two-dimensional ground-water flow model; and (3) presents results of model simulations, including steady-state water-table altitudes and average ground-water velocities and flow paths from the landfill site.

\section{Location of Study Area}

The study area (figs. 1 and 2) is bounded on the west by the Swan River, to the east by the Carmans River, and on the south by Bellport and Patchogue Bays. The northern boundary of the study area (which does not represent a hydrologic boundary) is defined by a line extending northeast from the headwaters of the Swan River to the downstream end of Lower Lake on the Carmans River (fig. 2). The Brookhaven landfill site, on Horseblock Road in Brookhaven hamlet, is in the center of the study area.

Land use in the study area is primarily residential; the highest residential density is in the western part. Much of the land in the eastern part remains undeveloped and consists mostly of scrub oak and pitch pine forest. The area also contains some agricultural land and light industry; conmercial development has taken place mostly along Montauk Highway and South 
Country Road (fig. 2). Preserved areas include Southhaven Park at the northeastern boundary, owned by Suffolk County, a New York State wetland area in the southeastern corner, and the Wertheim National Wildlife Refuge, just beyond the eastern boundary (fig. 2 ).

\section{Previous Investigations}

Early hydrogeologic investigations of Long Island that encompassed the general study area include a study of the ground-water resources by Veatch and others (1906) and a study of the geology by Fuller (1914). Suter and others (1949) mapped the geologic formations and aquifers of Long Island.

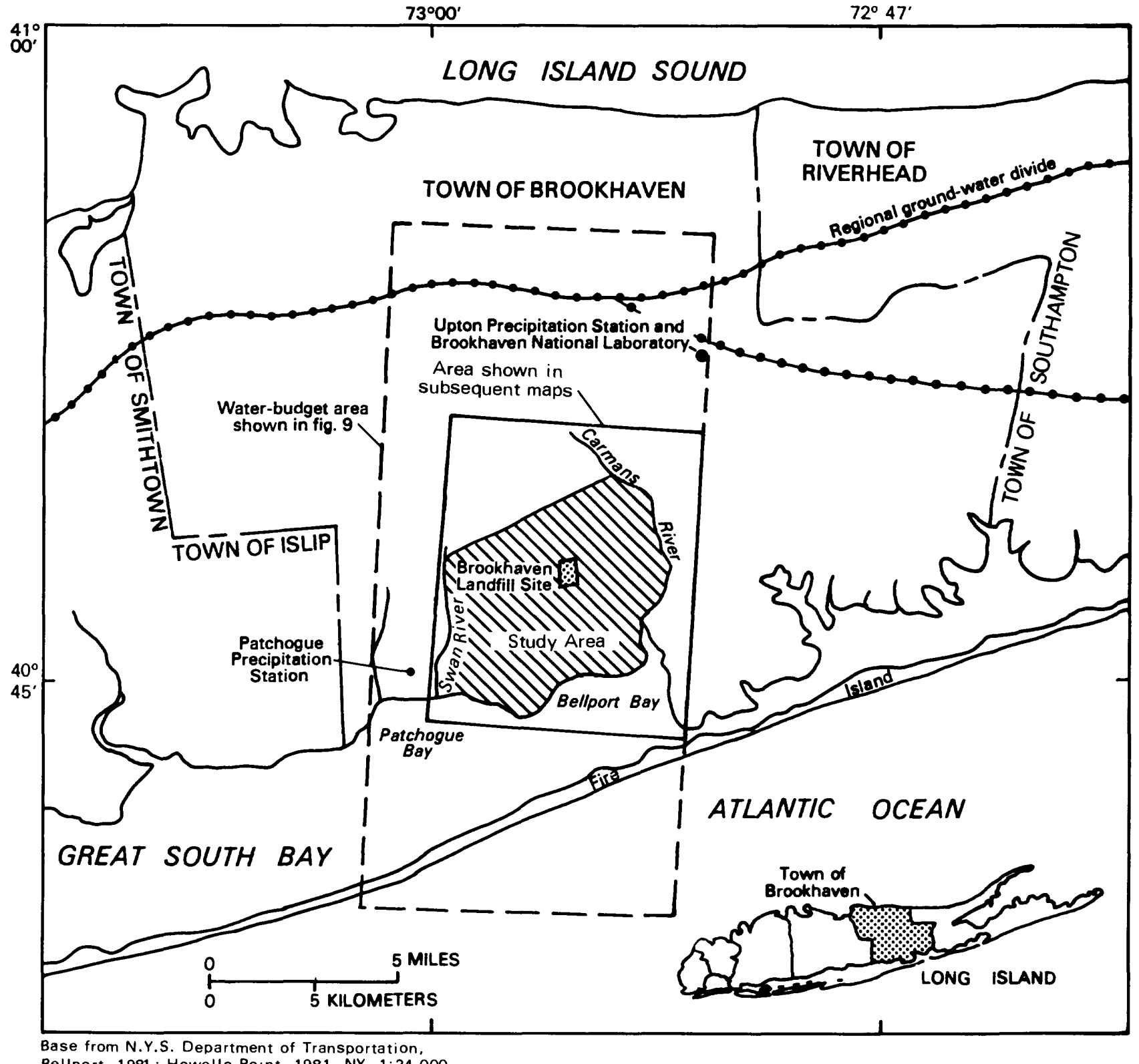

Bellport, 1981; Howells Point, 1981, NY, 1:24,000

Figure 1.--Location of $26-m i^{2}$ study area surrounding Brookhaven landfill site. 


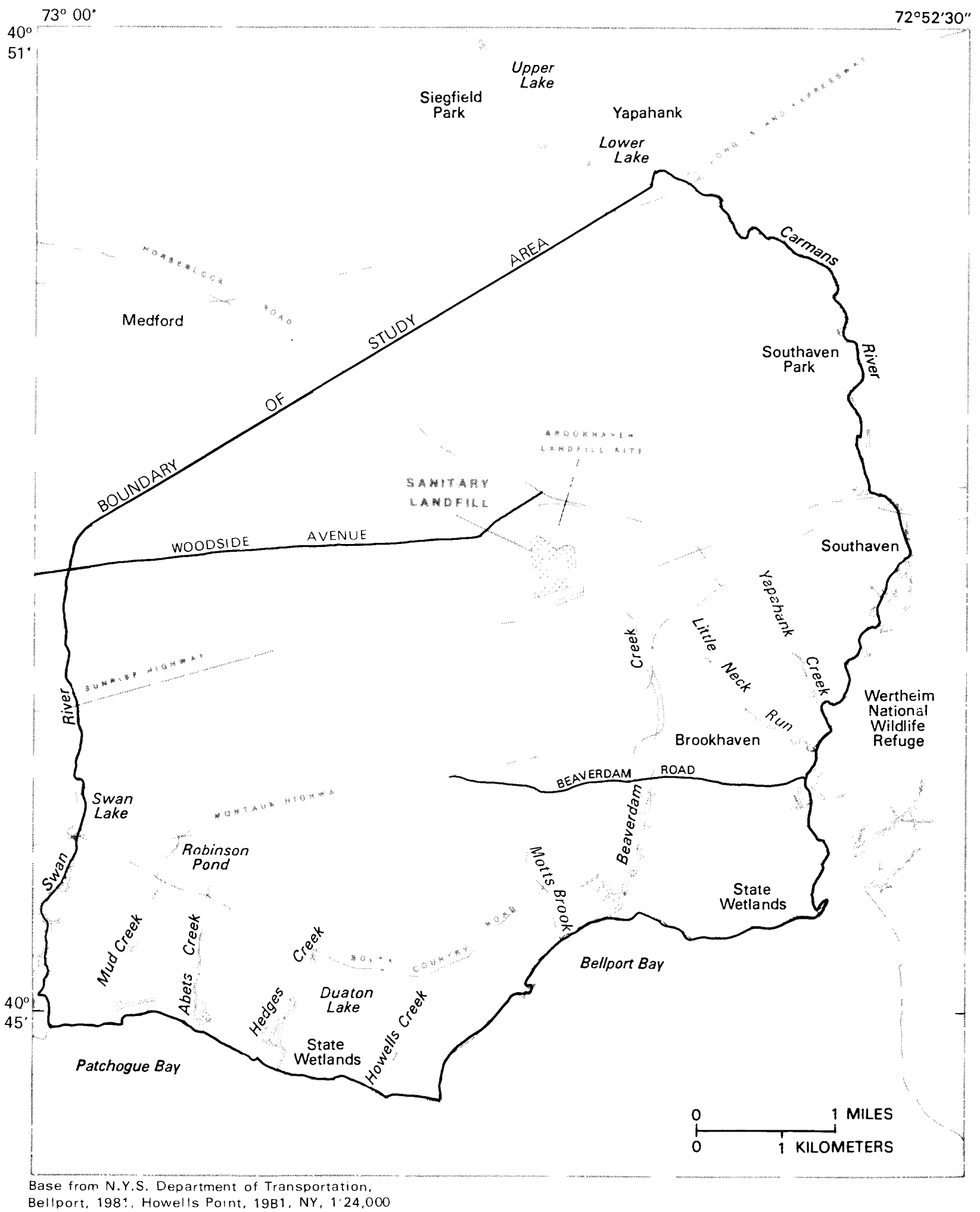

Figure 2.--Major geographic features of the modeled area. (Location is shown in fig. 1.) 
More recent studies of the hydrologic system of Long Island include Franke and McClymonds (1972) and Cohen and others (1968). Miller and Frederick (1969) discussed the precipitation regime of Long Island. Nakao and Erlichman (1978) and Donaldson and Koszalka (1983b) compiled water-table maps of Long Island, and Prince (1976) and Donaldson and Koszalka (1983a) compiled potentiometric-surface maps of the Magothy aquifer.

Streamflows, ground-water levels, and water-quality data are collected regularly by the U.S. Geological survey and cooperating agencies. These data are published annually by the U.S. Geological Survey.

Studies dealing specifically with Suffolk County include a compilation of hydrogeologic data from wells (Jensen and Soren, 1971) and maps of the surface and subsurface geology of Suffolk County (Jensen and Soren, 1974). Krulikas (1981) compiled additional data on wells drilled in Suffolk County during 1972-80.

The Geological Survey studied the hydrogeology of the Brookhaven National Laboratory (fig. 1) and the surrounding area during 1948-55; that investigation covered the central part of suffolk County and included most of the study area referred to herein. De Laguna (1963) described the stratigraphy of central Suffolk County and discussed the water-bearing properties of the geologic units; Warren and others (1968) described the hydrology of the area and presented data on climate, precipitation, evapotranspiration, ground-water flow and streamflow.

Models of the regional ground-water flow system of Long Island were developed by Getzen (1977) and Reilly and Harbaugh (1980). Reilly and others (1983) describe the use of subregional models to analyze the effects of sanitary sewers in parts of southern Nassau and Suffolk Counties on ground-water levels and discharge to streams.

\section{Acknowledgments}

The authors thank Herbert Buxton, Thomas Reilly, and Keith Prince of the U.S. Geological Survey for their advice during the model-development phase of this study.

\section{GEOHYDROLOGY}

Long Island is underlain by Precambrian bedrock that dips gently southward. Bedrock-surface altitude in the center of the study area is about $1,700 \mathrm{ft}$ below sea level (Jensen and Soren, 1974). Overlying the bedrock is a series of unconsolidated deposits that form Long Island's principal aquifers and confining units. Major characteristics of the hydrogeologic units in the study area are summarized in table 1 and shown in section in figure 3 . The major water-bearing units on the island, which are continuous throughout the study area, are the Lloyd and Magothy aquifers of Cretaceous age and the upper glacial aquifer of Pleistocene age, which is the aquifer of primary concern in this study. A discussion of the hydrologic properties of the principal aquifers and confining units is given in the following sections. 


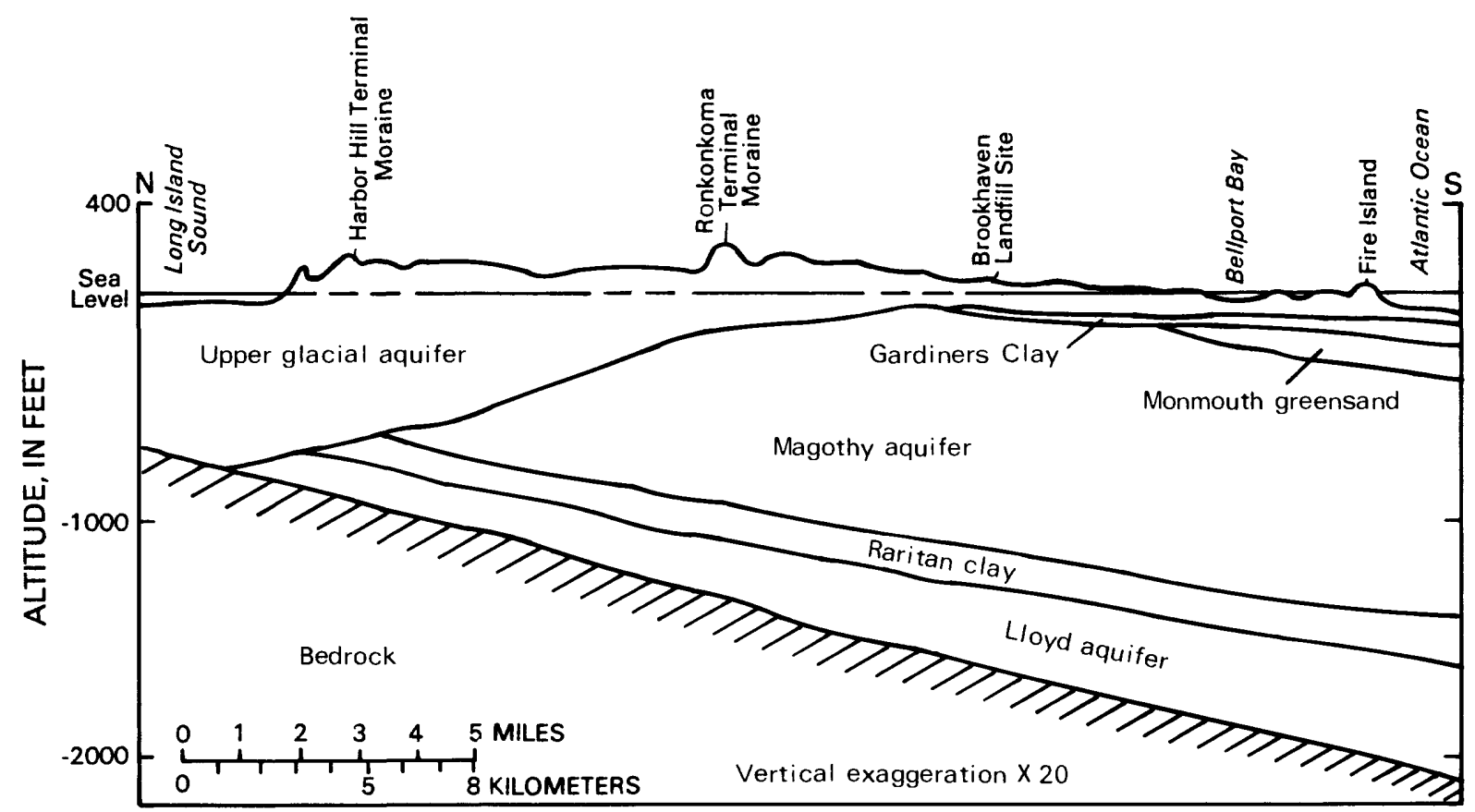

Figure 3.--Generalized north-south hydrogeologic section through the Town of Brookhaven showing relative positions of the principal aquifers and confining units. (Modified from Jensen and Soren, 1974.)

\section{Lloyd Aquifer and Raritan Clay}

The Lloyd aquifer in the Cretaceous Lloyd Sand Member of the Raritan Formation rests directly on the bedrock surface and is effectively confined by the clay member of the Raritan Formation. In the center of the study area, the Lloyd aquifer and Raritan clay are approximately $300 \mathrm{ft}$ and $200 \mathrm{ft}$ thick, respectively (Jensen and Soren, 1974).

Few data are available on the propertjes of the Lloyd aquifer and Raritan clay because no wells have penetrated these units in the modeled area. McClymonds and Franke (1972) estimate the average hydraulic conductivity of the Lloyd aquifer in south-central Suffolk County to be $36 \mathrm{ft} / \mathrm{d}$. The vertical hydraulic conductivity of the Raritan clay is estimated to average $0.001 \mathrm{ft} / \mathrm{d}$ (Franke and Cohen, 1972).

Recharge to the Lloyd aquifer takes place mostly within a narrow zone along the regional ground-water divide (fig. 1). Water in the Lloyd eventually discharges to the ocean south of the study area. The amount of downward leakage through the Raritan clay in the study area is extremely small; therefore, the effect of leakage to the Lloyd aquifer on ground-water flow in the overlying aquifers was not addressed in this study. 
Table 1.--Principal aquifers and confining units underlying Town of Brookhaven.

[Modified from Jensen and Soren, 1971]

\begin{tabular}{cccc}
$\begin{array}{c}\text { Hydrogeologic } \\
\text { unit }\end{array}$ & $\begin{array}{c}\text { Geologic } \\
\text { unit }\end{array}$ & $\begin{array}{c}\text { Approximate } \\
\text { thickness } \\
\text { (ft) }\end{array}$ & $\begin{array}{c}\text { Description and } \\
\text { water-bearing character }\end{array}$ \\
\hline $\begin{array}{c}\text { Upper glacial } \\
\text { aquifer }\end{array}$ & $\begin{array}{c}\text { Upper Pleistocene } \\
\text { deposits }\end{array}$ & $0-\quad 750$ & $\begin{array}{c}\text { Mainly brown and gray sand and gravel of } \\
\text { medium to high hydraulic conductivity; } \\
\text { also includes deposits of clayey till } \\
\text { and lacustrine clay of low hydraulic } \\
\text { conductivity major aquifer and } \\
\text { source of water for the study area. }\end{array}$ \\
\hline
\end{tabular}

$\begin{array}{cc}\text { Gardiners } & \text { Gardiners } \\ \text { Clay } & \text { Clay }\end{array}$

$0-75$

Green and gray clay, silt, clayey and silty sand, and some interbedded clayey and silty gravel. Unit has low hydraulic conductivity and tends to confine water in underlying aquifer.

Monmouth
greensand $\quad$ Monmouth Group 200

Interbedded marine deposits of dark gray, olive-green, dark greenish-gray, and greenish-black glauconitic and lignitic clay, silt, and clayey and silty sand. Unit has low hydraulic conductivity and tends to confine water in underlying aquifer.

$\begin{array}{ll}\begin{array}{c}\text { Magothy } \\ \text { aquifer }\end{array} & \begin{array}{l}\text { Matawan Group and } \\ \text { Magothy Formation, } \\ \text { undifferentiated }\end{array}\end{array}$

Gray and white fine-to-coarse sand of medium hydraulic conductivity. Generally contains sand and gravel beds of low to high hydraulic conductivity in basal 100 to $200 \mathrm{ft}$. Contains much interstitial clay and silt, and beds and lenses of clay of low hydraulic conductivity. A major aquifer although not highly developed in study area.

\begin{tabular}{|c|c|c|c|c|}
\hline $\begin{array}{c}\text { Raritan } \\
\text { clay }\end{array}$ & $\begin{array}{l}\text { Unnamed clay member } \\
\text { of the Raritan } \\
\text { Formation }\end{array}$ & $0-$ & 200 & $\begin{array}{l}\text { Gray, black, and multicolored clay and } \\
\text { some silt and fine sand. Unit has low } \\
\text { hydraulic conductivity and tends to } \\
\text { confine water in underlying aquifer. }\end{array}$ \\
\hline $\begin{array}{l}\text { Lloyd } \\
\text { aquifer }\end{array}$ & $\begin{array}{l}\text { Lloyd Sand Member } \\
\text { of the Raritan } \\
\text { Formation }\end{array}$ & $0-$ & 500 & $\begin{array}{l}\text { White and gray fine to coarse sand and } \\
\text { gravel of medium hydraulic conduc- } \\
\text { tivity and some clayey beds of low } \\
\text { hydraulic conductivity. A major } \\
\text { aquifer although not developed as a } \\
\text { source of water in study area. }\end{array}$ \\
\hline Bed rock & $\begin{array}{l}\text { Undifferentiated } \\
\text { crystalline } \\
\text { rocks }\end{array}$ & \multicolumn{2}{|c|}{ Unknown } & $\begin{array}{l}\text { Mainly metamorphic rocks of low hydrau- } \\
\text { lic conductivity; surface generally } \\
\text { weathered; considered to be the bottom } \\
\text { of the ground-water reservolr. }\end{array}$ \\
\hline
\end{tabular}




\section{Magothy Aquifer}

The Magothy aquifer in the undifferentiated Cretaceous Magothy Formation and overlying Matawan Group rests on the Raritan clay. The generalized configuration of the Magothy surface is depicted by Jensen and Soren (1974); within the study area it ranges between 100 and $200 \mathrm{ft}$ below sea level. Three test holes (wells S72812, S72813, and S72814 in fig. 5) drilled near the Brookhaven landfill site in 1982 indicate that the surface is about $120 \mathrm{ft}$ below sea level at the site. The thickness of the Magothy aquifer in the center of the study area is about $950 \mathrm{ft}$ (Jensen and Soren, 1974).

The Magothy aquifer consists mostly of gray and white fine quartz sand, clayey and silty sand, and clay (Pluhowski and Kantrowitz, 1964). Highly permeable zones of medium to coarse sand are interspersed irregularly throughout the formation. Clay layers, some as much as $50 \mathrm{ft}$ thick, also occur within the formation but are not continuous over large areas (Warren and others, 1968). The lower part of the Magothy aquifer is more permeable than the upper part and is tapped by several public-supply wells in the study area.

The average horizontal hydraulic conductivity of the Magothy aquifer in south-central Suffolk County is estimated to be $48 \mathrm{ft} / \mathrm{d}$ (McClymonds and Franke, 1972). Ratios of vertical to horizontal hydraulic conductivity may range from 1:30 to 1:40 (Getzen, 1977).

\section{Monmouth Greensand}

The Monmouth greensand in the Monmouth Group, a marine deposit of Cretaceous age, overlies the Magothy aquifer in the southern part of the study area. This unit consists of interbedded clay, silt, and sand containing glauconite and lignite. The northern limit of the Monmouth greensand lies approximately along Montauk Highway in the western part of the study area and along Beaverdam Road in the eastern part (fig. 2) (Jensen and Soren, 1974). The unit thickens to the south, attaining a thickness of 80 to $100 \mathrm{ft}$ beneath the barrier islands ( $f$ ig. 3 ).

\section{Gardiners Clay}

Resting on the surface of the Monmouth greensand but extending farther north is the Gardiners Clay--a marine clay deposited during the Sangamon interglaciation. De Laguna (1963) described the Gardiners Clay as a thin bed of green clay or clay and sand, generally $10 \mathrm{ft}$ thick, that lies $100 \mathrm{ft}$ or more below sea level. The green color is due to small amounts of glauconite and green clay minerals. Zones of sand or silt are common throughout the formation (de Laguna, 1963).

The Gardiners Clay was identified in core samples from we11s 572813 and S72814 (fig. 4) and consists of green clay and silt with some interbedded sand and gravel. In the vicinity of the Brookhaven landfill site, the Gardiners Clay has been reported as a sandy facies, which may be indicative of its northern limit (T. P. Doriski, U.S. Geological Survey, written commun., 1982). Cores and geophysical logs from these wells indicate that the unit is 8 to 12 ft thick. 


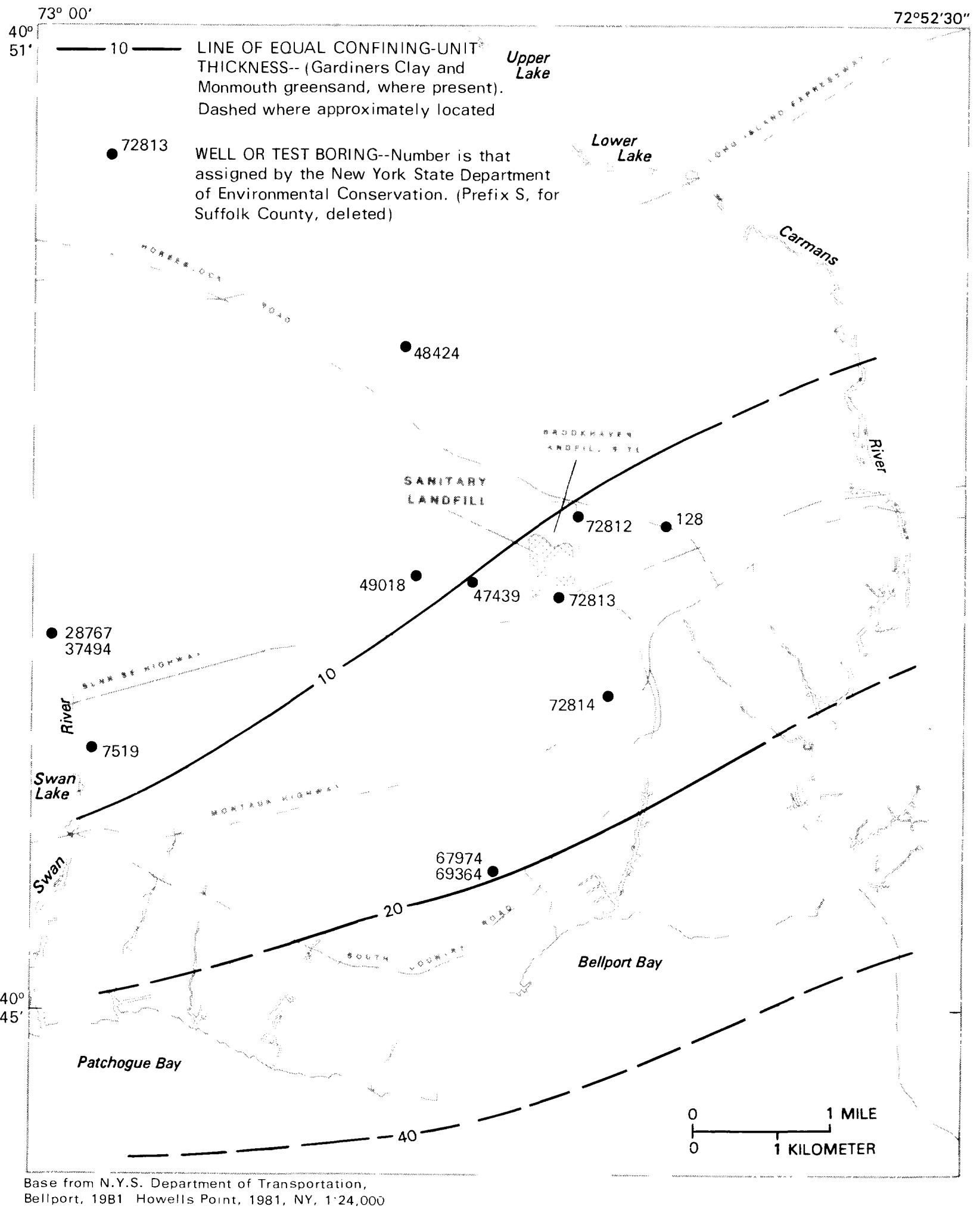

Figure 4.--Thickness of confining units (Gardiners Clay and Monmouth greensand) beneath upper glacial aquifer in study area. 
The Gardiners Clay has an estimated thickness of $15 \mathrm{ft}$ at the northern limit of the Monmouth greensand. Together, these semiconfining units have an estimated thickness of $40 \mathrm{ft}$ in the southern part of the study area. A map showing the combined thickness of the two units is shown in figure 4.

Vertical hydraulic conductivity of the Gardiners Clay in southwestern Suffolk County and southeastern Nassau County was determined by Reilly and others (1983) to range from $1.84 \times 10^{-2}$ to $2.21 \times 10^{-5} \mathrm{ft} / \mathrm{d}$, with a mean value of $2.9 \times 10^{-3} \mathrm{ft} / \mathrm{d}$. Warren and others (1968) estimated a vertical hydraulic conductivity of $4.0 \times 10^{-2} \mathrm{ft} / \mathrm{d}$ for the vicinity of the Carmans River ( $\mathrm{fig}$. 2 ). Getzen (1977) assumed a vertical hydraulic conductivity of $7.0 \times 10^{-2}$ $\mathrm{ft} / \mathrm{d}$ for both the Gardiners Clay and Monmouth greensand unit in his regional flow model of Long Island through analogy with clay units of similar origin in Connecticut.

\section{Upper Glacial Aquifer}

The upper glacial aquifer is composed of upper Pleistocene outwash from the Wisconsin glaciation. These deposits overlie the Gardiners Clay in the southern part of the study area and lie directly on the Magothy aquifer where the Gardiners Clay is missing. The base of the aquifer dips gently to the south and is about $105 \mathrm{ft}$ below sea level in the vicinity of the Brookhaven landfill site. The generalized configuration of the base of the upper glacial aquifer is shown in figure 5 .

The outwash deposits consist of interbedded fine to very coarse quartzose sand and gravel and some lenses of clay or silty sand. De Laguna (1963) observed that the lower part of the outwash generally consists of finer deposits than the upper part. At all three wells drilled in the landfill vicinity, the lower 10 to $15 \mathrm{ft}$ of the aquifer consists of silty reddish-brown sand containing micaceous material. The lateral extent of the silty layer is unknown.

Ground water in the upper glacial aquifer is under unconfined (watertable) conditions. The thickness of the unsaturated zone within the study area depends on the topography and water-table altitude and ranges from 0 to more than $80 \mathrm{ft}$. The saturated thickness of the aquifer ranges from 100 to $150 \mathrm{ft}$.

The upper glacial aquifer has medium to high hydraulic conductivity. Maps by McClymonds and Franke (1972) indicate the hydraulic conductivity in the study area to be about $267 \mathrm{ft} / \mathrm{d}$. Warren and others (1968) calculated a value of $174 \mathrm{ft} / \mathrm{d}$ from a pumping test at Brookhaven National Laboratory (fig. 1). They also analyzed seepage into the Carmans River along a reach between two gaging stations (station 01305000 and station 01305040 in pl. 1) and calculated a hydraulic conductivity of $187 \mathrm{ft} / \mathrm{d}$. 


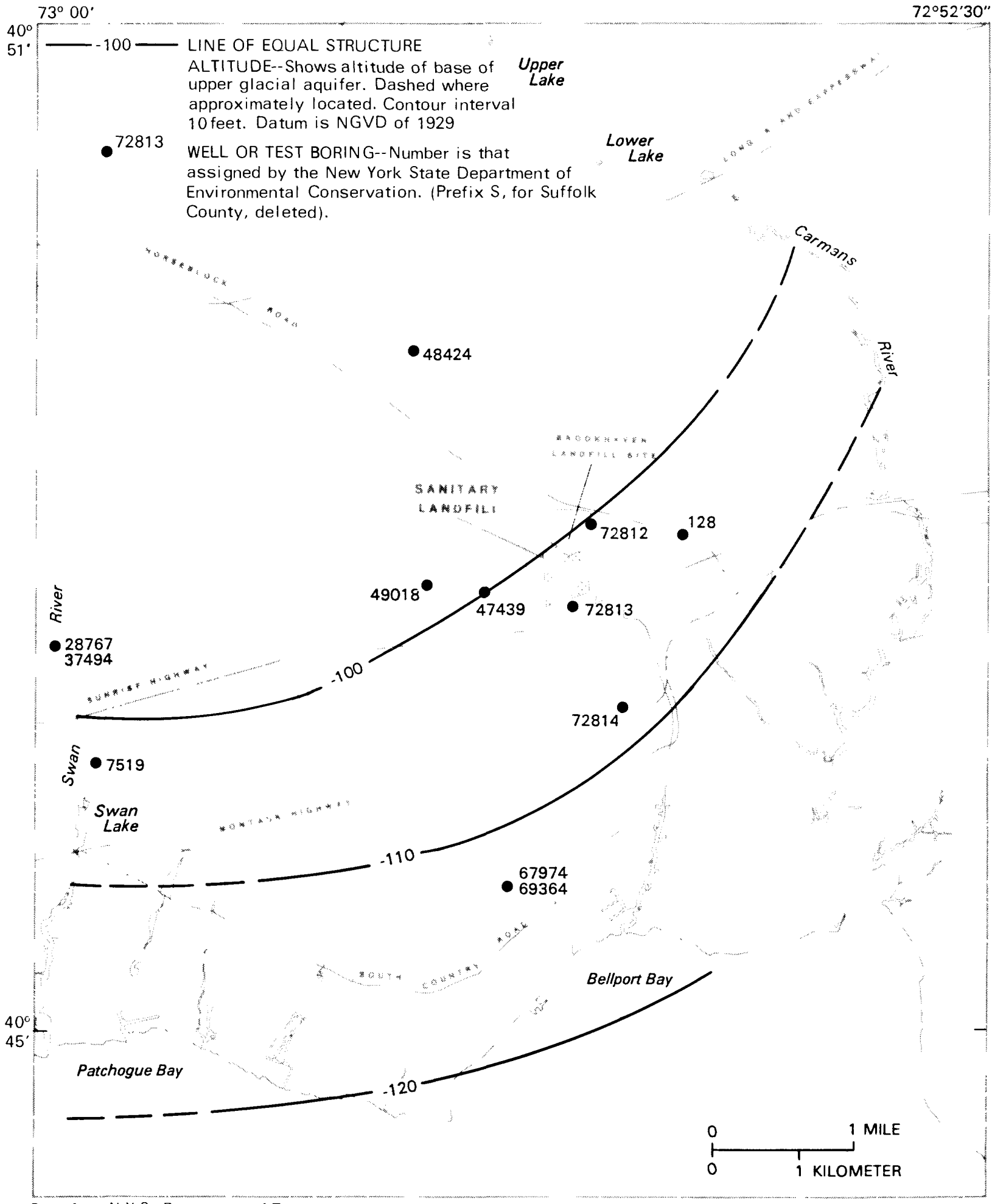

Base from N.Y.S. Department of Transportation,

Bellport, 1981. Howells Point, 1981, NY, 1:24,000

Figure 5.--Configuration of base of upper glacial aquifer in study area. 


\section{GROUND-WATER FLOW SYSTEM}

The regional ground-water flow system on Long Island has been described in many reports, including those by Cohen and others (1968), Franke and McClymonds (1972), and Getzen (1977). A generalized vertical section illustrating the flow pattern south of the regional ground-water divide, which trends east-west across Long Island ( $f i g .1$ ), is shown in figure 6.

The ground-water reservoir is recharged by precipitation that infiltrates the land surface and seeps down to the water table. Most water moves laterally through the upper glacial aquifer, but some continues downward into the underlying Magothy and Lloyd aquifers. Ground water in the study area generally travels southward and eventually discharges into Bellport and Patchogue Bays and to streams flowing to these bays (fig. 2). Water in the deeper part of the upper glacial aquifer may pass beneath shallow flow systems associated with streams as it moves toward the shore. The following sections describe major sources and locations of ground-water recharge and discharge.

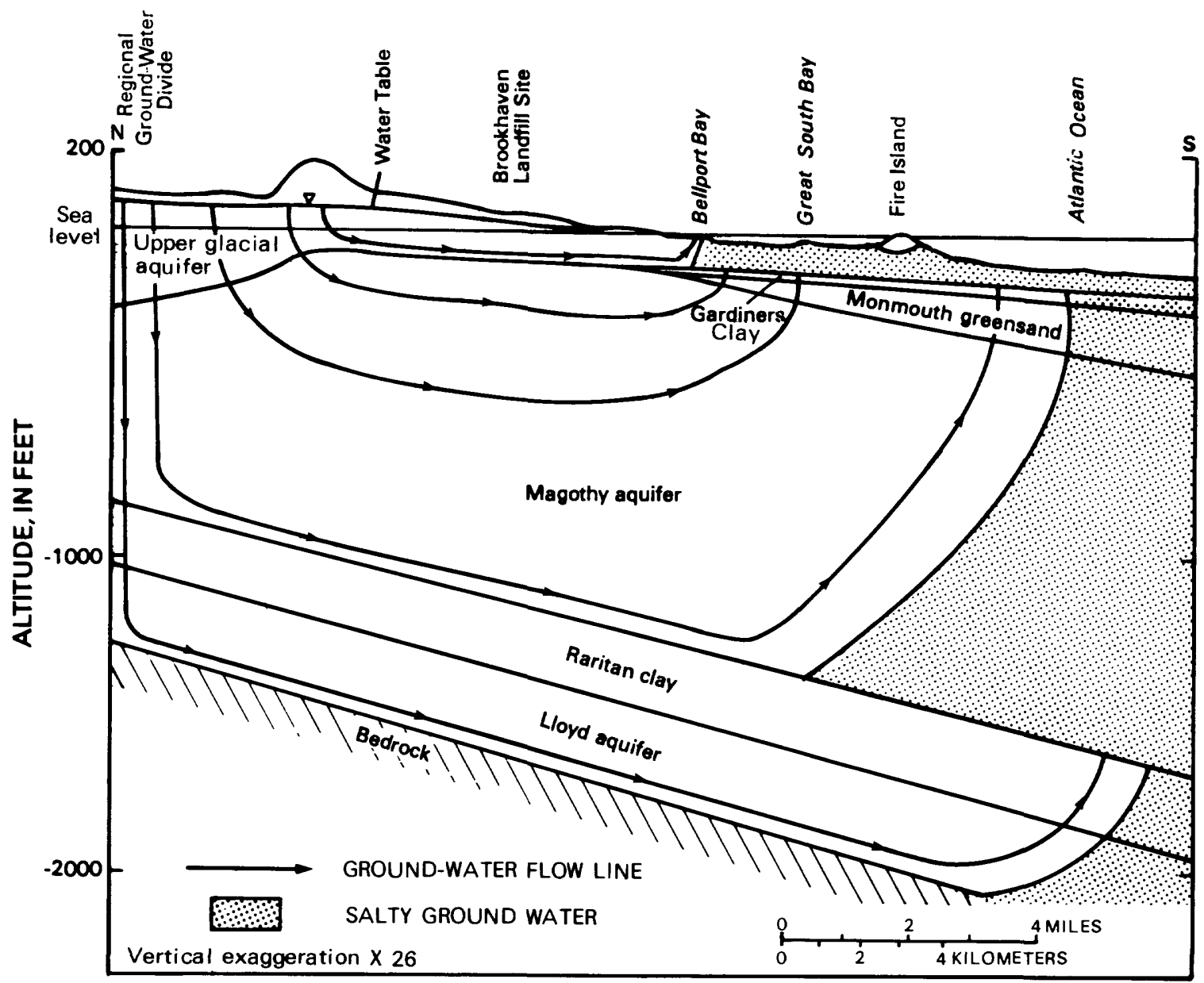

Figure 6.--Generalized north-south hydrogeologic section of the ground-water system south of the regional groundwater divide showing pattern of ground-water flow. 


\section{Recharge}

\section{Precipitation and E'vapotranspiration}

Precipitation on Long Island averages 43 in/yr (Miller and Frederick, 1969). The average warm-season and cool-season precipitation amounts are approximately equal. The areal distribution of precipitation is uneven and is greatest over the central part of Long Island.

Average annual precipitation in the study area during 1951-65 was 45.5 inches (Miller and Frederick, 1969). Annual precipitation during 1973-82 and average monthly and average annual precipitation for the period of record at the Patchogue and Upton precipitation stations ( $f$ ig. 1 ) are presented in table 2 .

An average value of 47.4 inches was calculated from the average annual precipitation for the period of record at the two stations; this value was used in the ground-water flow model, described further on.

Table 2.--Annual, average monthly, and average annual precipitation at Patchogue and Upton.

[Al1 values are in inches; station locations are shown in fig. 1]

\begin{tabular}{lllllll}
\hline & \multicolumn{2}{c}{ A. Annual precipitation, 1973-82 } \\
\hline \multirow{2}{*}{ Year } & \multicolumn{2}{c}{ Station* } & & \multicolumn{2}{c}{ Station* } \\
\cline { 2 - 3 } \cline { 6 - 7 } & Patchogue & Upton & Year & Patchogue & Upton \\
1973 & 52.46 & 52.75 & & 1978 & 53.89 & 53.49 \\
1974 & 44.56 & 41.80 & & 1979 & 62.45 & 56.12 \\
1975 & 55.43 & 52.88 & 1980 & 38.68 & 35.17 \\
1976 & 47.60 & 45.16 & 1981 & 41.61 & 40.03 \\
1977 & 55.44 & 53.78 & 1982 & 47.26 & 48.42 \\
\hline
\end{tabular}

*Patchogue: $40^{\circ} 45^{\prime} 06^{\prime \prime}$ lat, $73^{\circ} 02^{\prime} 28^{\prime \prime}$ long Upton: $\quad 40^{\circ} 52^{\prime} 14^{\prime \prime}$ lat, $72^{\circ} 53^{\prime} 30^{\prime \prime}$ long

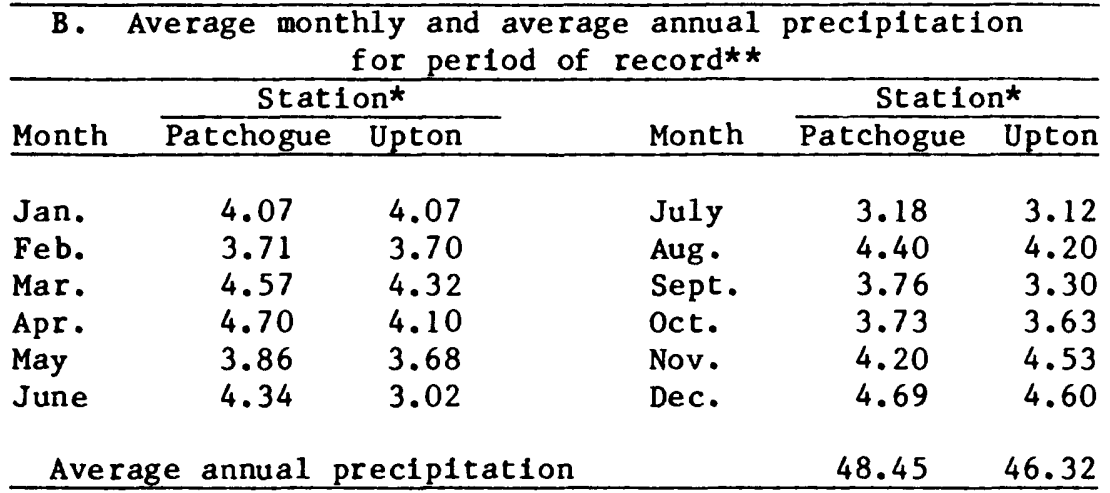

**Patchogue period of record: 1-66 through 12-82

Upton period of record: 1-43 through 12-82 
Not all precipitation is available for recharge; some evaporates from land surface, is transpired by plants, and runs overland to streams. Surface runoff in undeveloped areas of Long Island is negligible because of the high permeability of the sandy soils (Warren and others, 1968). Surface runoff in developed areas is greater, but most of this water is channeled to stormwaterrecharge basins, where the water infiltrates and subsequently recharges the aquifer.

Cohen and others (1968) estimate that half the annual precipitation on Long Island reaches the water table. Warren and others (1968) used the Thornthwaite method to calculate losses due to evapotranspiration in the Brookhaven National Laboratory vicinity (fig. 1) and also concluded that approximately 50 percent of the precipitation reaches the water table. Recent regional modeling studies have used 52 percent of precipitation as the estimated recharge value (D. A. Smolensky, U.S. Geological Survey, oral commun., 1984). Accordingly, a uniform $24.6 \mathrm{in./yr}$ was assumed to recharge ground water in the study area.

\section{Other Sources of Ground-Water Recharge}

The upper glacial aquifer is also recharged by injection of spent cooling water through diffusion wells, by infiltration of domestic and industrial wastewater through cesspools and septic tanks, and by irrigation return flow. These mechanisms add no additional recharge to the aquifer beyond the natural amount but, rather, serve as mechanisms for the return and redistribution of water withdrawn from the aquifer. Similarly, recharge basins in developed areas intercept water that would otherwise be lost as runof $f$ to streams and thus help maintain the natural level of recharge.

Most of the redistributed water is reapplied close to the point of withdrawal, and the overall affect on ground-water flow is presumed to be negligible. The most significant redistribution of recharge in the study area is the discharge of treated wastewater from sewage-treatment plants into unlined basins. Sewage-treatment plants in the study area and their reported discharge rates are listed in table 3; their locations are shown on plate 1.

Table 3.--Sewage-treatment-plant discharge to ground water in study area, 1981.

[Data from New York State Department of Environmental Conservation; locations are shown on pl. 1]

\begin{tabular}{|c|c|c|c|}
\hline $\begin{array}{c}\text { Sewage-treatment } \\
\text { plant }\end{array}$ & \multicolumn{2}{|c|}{ Latitude/Longitude } & $\begin{array}{l}\text { Discharge } \\
(\mathrm{Mgal} / \mathrm{d})\end{array}$ \\
\hline Woodside Sites & $40^{\circ} 47^{\prime} 40^{\prime \prime}$ & $72^{\circ} 57^{\prime} 34^{\prime \prime}$ & 0.467 \\
\hline $\begin{array}{l}\text { Brookhaven Memorial } \\
\text { Hospital }\end{array}$ & $40^{\circ} 46^{\prime} 49^{\prime \prime}$ & $72^{\circ} 58^{\prime} 37^{\prime \prime}$ & .091 \\
\hline Levitt House & $40^{\circ} 47^{\prime} 44^{\prime \prime}$ & $72^{\circ} 58^{\prime} 10^{\prime \prime}$ & .467 \\
\hline Suffolk County Center & $40^{\circ} 48^{\prime} 40^{\prime \prime}$ & $72^{\circ} 55^{\prime} 16^{\prime \prime}$ & .06 \\
\hline
\end{tabular}




\section{Discharge}

The main components of discharge from the ground-water reservoir under natural conditions are seepage to streams, ground-water evapotranspiration, and subsurface outflow (Franke and McClymonds, 1972). Subsurface outflow from the upper glacial aquifer is difficult to quantify because data on head gradients along the shore are lacking. Estimates of subsurface outflow can be made by subtracting the sum of all other discharges from the total inflow and recharge to the study area; this procedure is discussed further in the discussion of the water-budget analysis.

Ground-water evapotranspiration occurs during the growing season, when vegetation withdraws ground water through root systems extending below the water table. On Long Island, this generally occurs only where the depth to ground water is less than $5 \mathrm{ft}$ below land surface (Pluhowski and Kantrowitz, 1964). Areas of shallow depth to water in the study area are found within short distances of stream channels and along the shore. The overall effect of ground-water evapotranspiration on ground-water flow in the study area is, therefore, presumed to be negligible.

Other components of discharge are related to development of the aquifer system and include pumpage for domestic and industrial water supply and for irrigation. Data on streamflow and pumpage are presented in the following sections.

\section{Seepage to Streams}

Interaction between streams and aquifers on Long Island has been described by several investigators (Harbaugh and Getzen, 1977; Cohen and others, 1968; Reynolds, 1982; and Prince, 1980). In the study area, discharge to streams has a significant effect on the pattern of ground-water flow within the upper glacial aquifer.

Under natural (undeveloped) conditions on Long Island, 90 to 95 percent of streamflow is derived from ground-water seepage; the rest consists of surface runoff. Bank storage is considered to be negligible (Cohen and others, 1968). Base flow in the two streams that bound the study area was calculated to be 96 percent of the total annual flow of the Carmans River and 92 percent of the Swan River during 1976-82 (D. S. Peterson, U.S. Geological Survey, written commun., 1983).

Base flow in Long Island streams responds to changes in water levels in the surrounding aquifer--that is, when the ground-water level beneath the stream rises, ground-water seepage into the stream increases. Rates of ground-water seepage also are controlled by the hydraulic conductivity of the streambed deposits, which is generally lower than that of the surrounding aquifer material, and by the streambed thickness. Prince (1980) studied Connetquot Brook--a major stream in an undeveloped area on the south shore of Long Island--and calculated the thickness of the streambed material to be approximately $3 \mathrm{ft}$ and the vertical hydraulic conductivity of streambed material to be $6.5 \mathrm{ft} / \mathrm{d}$ (K. R. Prince, U.S. Geological Survey, written commun., 1983). 
The length of the flowing part of a stream varies seasonally and from year to year in response to fluctuations in the ground-water levels. Flow begins where the water table first intersects the base of the stream channel; this point is commonly referred to as the start-of-flow. As ground-water levels fluctuate, the start-of-flow moves upstream or downstream accordingly.

The study area has 11 major streams, all of which flow southward and discharge to Bellport Bay or Patchogue Bay. Locations of these streams and their start-of-flow are shown on plate 1 ; estimated average base flows for streams having continuous or partial discharge measurements are presented in table 4. Descriptions of the 11 streams in the study area are given on page 17. All are gaining (influent) streams throughout their length except where they are ponded behind manmade controls. Local circulation patterns develop near these ponded sections, where stream water discharges to the aquifer near the downstream end of the pond and then seeps back into the stream downstream of the control.

Table 4.--Average base flow at partial-and continuous-record stations in study area.

[Locations are shown on p1.1]

\begin{tabular}{|c|c|c|c|c|c|}
\hline $\begin{array}{c}\text { Streain } \\
\text { name }\end{array}$ & $\begin{array}{c}\text { Station- } \\
\text { identification } \\
\text { number } \\
\end{array}$ & Latitude/ & Long i tude & $\begin{array}{c}\text { Station } \\
\text { type } 1 \\
\end{array}$ & $\begin{array}{c}\text { Estimated } \\
\text { ave rage } \\
\text { base f1ow, } \\
1976-82^{2} \\
\left(\mathrm{ft}^{3} / \mathrm{s}\right)\end{array}$ \\
\hline Carmans River & $\begin{array}{l}01304998 \\
01305000 \\
01305040\end{array}$ & $\begin{array}{l}40^{\circ} 50^{\prime} 07^{\prime \prime} \\
40^{\circ} 49^{\prime} 49^{\prime \prime} \\
40^{\circ} 48^{\prime} 09^{\prime \prime}\end{array}$ & $\begin{array}{l}72^{\circ} 55^{\prime} 01^{\prime \prime} \\
72^{\circ} 54^{\prime} 24^{\prime \prime} \\
72^{\circ} 53^{\prime} 09^{\prime \prime}\end{array}$ & $\begin{array}{l}\mathrm{PR} \\
\mathrm{C} \\
\mathrm{PR}\end{array}$ & $\begin{array}{l}19.84 \\
26.28 \\
56.0\end{array}$ \\
\hline Yapahank Creek & $\begin{array}{l}\text { YC-1 } \\
01305050\end{array}$ & $\begin{array}{l}40^{\circ} 47^{\prime} 44^{\prime \prime} \\
40^{\circ} 47^{\prime} 26^{\prime \prime}\end{array}$ & $\begin{array}{l}72^{\circ} 54^{\prime} 12^{\prime \prime} \\
72^{\circ} 54^{\prime} 05^{\prime \prime}\end{array}$ & $\begin{array}{l}\mathrm{T} \\
\mathrm{PR}\end{array}$ & $\begin{array}{l}.12 \\
.8\end{array}$ \\
\hline Little Neck Run & 01305070 & $40^{\circ} 47^{\prime} 11^{\prime \prime}$ & $72^{\circ} 54^{\prime} 38^{\prime \prime}$ & PR & .1 \\
\hline Beaverdam Creek & $\begin{array}{l}\text { BD-1 } \\
01305095 \\
\text { BD-3 } \\
01305100\end{array}$ & $\begin{array}{l}40^{\circ} 47^{\prime} 19^{\prime \prime} \\
40^{\circ} 47^{\prime} 01^{\prime \prime} \\
40^{\circ} 46^{\prime} 54^{\prime \prime} \\
40^{\circ} 46^{\prime} 42^{\prime \prime}\end{array}$ & $\begin{array}{l}72^{\circ} 55^{\prime} 10^{\prime \prime} \\
72^{\circ} 55^{\prime} 02^{\prime \prime} \\
72^{\circ} 55^{\prime} 00^{\prime \prime} \\
72^{\circ} 54^{\prime} 59^{\prime \prime}\end{array}$ & $\begin{array}{l}\mathrm{T} \\
\mathrm{PR} \\
\mathrm{T} \\
\mathrm{PR}\end{array}$ & $\begin{array}{l}.24 \\
.737 \\
1.20 \\
1.35\end{array}$ \\
\hline Motts Brook & 01305200 & $40^{\circ} 45^{\prime} 45^{\prime \prime}$ & $72^{\circ} 55^{\prime} 52^{\prime \prime}$ & PR & 1.27 \\
\hline Hedges Creek & 01305240 & $40^{\circ} 45^{\prime} 22^{\prime \prime}$ & $72^{\circ} 57^{\prime} 44^{\prime \prime}$ & PR & .90 \\
\hline Abets Creek & 01305280 & $40^{\circ} 45^{\prime} 42^{\prime \prime}$ & $72^{\circ} 58^{\prime} 37^{\prime \prime}$ & PR & .10 \\
\hline Mud Creek & 01305300 & $40^{\circ} 45^{\prime} 47^{\prime \prime}$ & $72^{\circ} 58^{\prime} 59^{\prime \prime}$ & PR & 3.75 \\
\hline Swan River & 01305500 & $40^{\circ} 46^{\prime} 01^{\prime \prime}$ & $72^{\circ} 59^{\prime} 39^{\prime \prime}$ & $\mathrm{C}$ & 12.18 \\
\hline
\end{tabular}

1 PR, partial-record station; C, continuous-record station; $T$, temporary station used only for this study. Discharge measurements on file at the U.S. Geological Survey, Syos set, N.Y.

2 D. S. Peterson, U.S. Geological Survey, written commun., 1983. 
Carmans River.--The largest of the 11 streams in the area, both in length and average annual discharge, the Carmans River forms the eastern boundary of the study area. The Carmans River is $12 \mathrm{mi}$ long, has an average gradient of $5.4 \mathrm{ft} / \mathrm{mi}$, and an average annual base $\mathrm{flow}$ of $56 \mathrm{ft} / \mathrm{s}$ at station 01305040 (pl. 1) (D. S. Peterson, U.S. Geological Survey, written commun., 1983). The Carmans River has five manmade controls--the dams that form Upper and Lower Lakes and three dams within Southhaven Park (fig. 2). The Carmans River is tidal south of Montauk Highway.

Swan River.--The second largest of the 11 streams, the Swan River has a length of $2.2 \mathrm{mi}$ and an average gradient of $13.8 \mathrm{ft} / \mathrm{mi}$. The dam that forms Swan Lake ( $p 1.1)$ is the only major manmade control on the river. Swan River becomes tidal south of the Long Island Railroad right-of-way (p1. 1). The start-of-flow point during the study was north of Woodside Avenue (p1. 1).

Beaverdam Creek.--The third largest stream in the study area, Beaverdam Creek has a length of $1.2 \mathrm{mi}$. The start-of-flow point is usually between Sunrise Highway and Montauk Highway. Beaverdam Creek has no major manmade controls, although some backwater effects occur above the point where the stream passes through culverts at Montauk Highway and South Country Road (p1. 1). The stream becomes tidal about $900 \mathrm{ft}$ south of South Country Road.

Yapahank Creek.--Yapahank Creek is $0.76 \mathrm{mi}$ 1ong. The start-of-flow is usual $1 \mathrm{y}$ a few hundred feet to either side of Montauk Highway (p1. 1). S1ight ponding occurs north of the Long Island Railroad right of way, where flow passes through a culvert beneath the tracks. Yapahank Creek is tida1 from approximately 1,000 ft south of Station 01305070 (pl. 1).

Little Neck Run.--Little Neck Run is ponded north of the Long Island Railroad right of way. The ponding results from clogging of the culvert that passes under the railroad tracks. Ground-water seepage is evident on the south side of the tracks. The stream becomes tidal approximately 1,000 ft south of the tracks.

Motts Brook.--Motts Brook is approximately $0.28 \mathrm{mi}$ long and begins near the end of Head of Neck road. Motts Brook is ponded north of South Country Road ( 1.1 ) and becomes tidal a few hundred feet to the south.

Other streams.--Two unnamed tributaries converge north of Montauk Highway and flow south into Robinson Pond, which is dammed at South Country Road. The eastern tributary is $0.70 \mathrm{mi}$ long; the western tributary is $0.30 \mathrm{mi}$ long. Robinson Pond discharges into Mud Creek, which becomes tidal a few hundred feet south of station 01305300 .

Few data on the three remaining streams in the study area (Hedges Creek, Howel ls Creek, and Abets Creek) are available. These streams are short and are tidal for most of their length. Hedges Creek discharges into Dunton Lake; Howells Creek and Abets Creek discharge into Bellport and Patchogue Bays. Estimates of annual average base flow in several of the streams are presented in table 4 . 
Major pumpage in the study area, as reported annually to the New York State Department of Environmental Conservation, is summarized in table 5. All wells listed are screened within the upper glacial aquifer; their locations are shown on plate 1. Seasonal pumpage for irrigation in the study area is minor and not included in table 5. The study area contains many private domestic supply wells, but pumpage from these wells is low, and most of the water is returned to the aquifer through discharge from cesspools. The overall effect of both irrigation and domestic pumpage on ground-water flow in the upper glacial aquifer is assumed to be minimal and was not accounted for in the ground-water flow model.

Table 5.--Public-supply and industrial pumpage in study area, 1981

[Data from New York State Department of Environmental Conservation; well locations are shown in $\mathrm{pl}$. 1]

\begin{tabular}{llllc}
\hline $\begin{array}{c}\text { We11 } \\
\text { number }\end{array}$ & \multicolumn{1}{c}{ Owner } & Latitude/Long1tude & $\begin{array}{c}\text { Total } \\
\text { pumpage } \\
\left(\mathrm{ft}^{3} / \mathrm{s}\right)\end{array}$ \\
\hline $\begin{array}{l}\text { S1331 } \\
\text { S14710 }\end{array}$ & SCWA - Bellport well field & $40^{\circ} 45^{\prime} 52^{\prime \prime}$ & $72^{\circ} 56^{\prime} 16^{\prime \prime}$ & 0.42 \\
$\begin{array}{l}\text { S52944 } \\
\text { S52945 }\end{array}$ & SCWA - Patchogue-Yaphank Road & & & \\
well field & $40^{\circ} 49^{\prime} 00^{\prime \prime}$ & $72^{\circ} 57^{\prime} 05^{\prime \prime}$ & 1.24 \\
S33826 & SCWA - Station Road we11 field & $40^{\circ} 47^{\prime} 39^{\prime \prime} 72^{\circ} 56^{\prime} 55^{\prime \prime}$ & .28 \\
S26616 & Bellport Village golf course & $40^{\circ} 45^{\prime} 03^{\prime \prime}$ & $72^{\circ} 57^{\prime} 00^{\prime \prime}$ & .069 \\
S16098 & Suffolk County Board of Supervisors & $40^{\circ} 48^{\prime} 43^{\prime \prime}$ & $72^{\circ} 55^{\prime} 16^{\prime \prime}$ & .041 \\
S43348 & Redactron Corp. & $40^{\circ} 48^{\prime} 41^{\prime \prime}$ & $72^{\circ} 56^{\prime} 56^{\prime \prime}$ & .0008 \\
\hline
\end{tabular}

1 SCWA, Suffolk County Water Authority

\section{Ground Water in the Upper Glacial Aquifer}

Ground water in the upper glacial aquifer is under water-table (unconfined) conditions throughout the study area. Water-table altitudes are influenced by the hydraulic conductivity of the aquifer, rates of recharge to and discharge from the aquifer, location of hydrologic boundaries, and the quantity of flow across these boundaries. Maps showing lines of equal water-table altitude can be used to determine gradients in hydraulic head and the direction of ground-water flow.

\section{Water-Table Altitudes in September 1982}

A network of 164 observation wells (including 102 added in this phase of the study) and 23 stream-stage-measurement sites were used to determine watertable altitudes; their locations are shown on plate 1. Data on the location, 
ownership, and physical characteristics of the observation wells are given in table 9 (at end of report); information on the stream-stage-measurement sites is given in table 6 .

A map showing lines of equal water-table altitude in the upper glacial aquifer in September 1982 is presented on plate 2. The map represents a period when water-table altitudes were close to the 5-year average, as indicated by hydrographs of four observation wells in the area (fig. 7). Streamflow in the Carmans and Swan Rivers during the first 2 weeks of September 1982 was near long-term average values (U.S. Geological Survey, 1983).

The configuration of the water table in September 1982 (p1. 2) is similar to that shown in maps prepared by Warren and others (1968) for periods of average water levels in August 1951 and July 1952. This indicates that ground water in the study area has not been greatly influenced by development since that time.

Ground water entering the study area at the northern boundary flows perpendicular to the lines of equal water-table altitude southward toward the shore and also westward and eastward toward the Swan River and the Carmans

\begin{tabular}{|c|c|c|c|}
\hline Stream name & $\begin{array}{c}\text { Station- } \\
\text { identification } \\
\text { number }\end{array}$ & \multicolumn{2}{|c|}{ Lat Itude/Long I tude } \\
\hline Carmans River & $\begin{array}{l}01304995 \\
\text { CR-9 } \\
01304998 \\
01305000 \\
C R-13 \\
C R-14 \\
C R-15 \\
C R-16 A \\
01305040 \\
01305041\end{array}$ & $\begin{array}{l}40^{\circ} 50^{\prime} 29^{\prime \prime} \\
40^{\circ} 50^{\prime} 08^{\prime \prime} \\
40^{\circ} 50^{\prime} 07^{\prime \prime} \\
40^{\circ} 49^{\prime} 49^{\prime \prime} \\
40^{\circ} 49^{\prime} 00^{\prime \prime} \\
40^{\circ} 48^{\prime} 59^{\prime \prime} \\
40^{\circ} 48^{\prime} 44^{\prime \prime} \\
40^{\circ} 48^{\prime} 10^{\prime \prime} \\
40^{\circ} 48^{\prime} 09^{\prime \prime} \\
40^{\circ} 45^{\prime \prime}\end{array}$ & $\begin{array}{l}72^{\circ} 56^{\prime} 13^{\prime \prime} " \\
72^{\circ} 55^{\prime} 02^{\prime \prime} \\
72^{\circ} 55^{\prime} 01^{\prime \prime} \\
72^{\circ} 54^{\prime} 24^{\prime \prime} \\
72^{\circ} 53^{\prime} 24^{\prime \prime} \\
72^{\circ} 53^{\prime} 24^{\prime \prime} \\
72^{\circ} 53^{\prime} 29^{\prime \prime} \\
72^{\circ} 53^{\prime} 10^{\prime \prime} \\
72^{\circ} 53^{\prime} 09^{\prime \prime} \\
72^{\circ} 04^{\prime \prime}\end{array}$ \\
\hline Yapahank Creek & 01305050 & $40^{\circ} 47^{\prime} 26^{\prime \prime}$ & $72^{\circ} 54^{\prime} 05^{\prime \prime}$ \\
\hline Little Neck Run & $\begin{array}{l}\text { LNR-1 } \\
01305070\end{array}$ & $\begin{array}{l}40^{\circ} 47^{\prime} 24^{\prime \prime} \\
40^{\circ} 47^{\prime} 11^{\prime \prime}\end{array}$ & $\begin{array}{l}72^{\circ} 54^{\prime} 45^{\prime \prime} \\
72^{\circ} 54^{\prime} 38^{\prime \prime}\end{array}$ \\
\hline Beaverdam Creek & $\begin{array}{l}\text { BD-1 } \\
01305095 \\
\text { BD-3 } \\
01305100\end{array}$ & $\begin{array}{l}40^{\circ} 47^{\prime} 19^{\prime \prime} \\
40^{\circ} 47^{\prime} 01^{\prime \prime} \\
40^{\circ} 46^{\prime} 54^{\prime \prime} \\
40^{\circ} 46^{\prime} 42^{\prime \prime}\end{array}$ & $\begin{array}{l}72^{\circ} 55^{\prime} 10^{\prime \prime} \\
72^{\circ} 55^{\prime} 02^{\prime \prime} \\
72^{\circ} 55^{\prime} 00^{\prime \prime} \\
72^{\circ} 54^{\prime} 59^{\prime \prime}\end{array}$ \\
\hline Motts Brook & 01305200 & $40^{\circ} 45^{\prime} 45^{\prime \prime}$ & $72^{\circ} 55^{\prime} 52^{\prime \prime}$ \\
\hline Mud Creek & 01305300 & $40^{\circ} 45^{\prime} 47^{\prime \prime}$ & $72^{\circ} 58^{\prime} 59^{\prime \prime}$ \\
\hline Swan River & $\begin{array}{l}\text { SL-1 } \\
\text { SR1 } \\
\text { SR2 } \\
01305500\end{array}$ & $\begin{array}{l}40^{\circ} 46^{\prime} 04^{\prime \prime} \\
40^{\circ} 46^{\prime} 52^{\prime \prime} \\
40^{\circ} 47^{\prime} 16^{\prime \prime} \\
40^{\circ} 46^{\prime} 01^{\prime \prime}\end{array}$ & $\begin{array}{l}72^{\circ} 59^{\prime} 39^{\prime \prime} \\
72^{\circ} 59^{\prime} 40^{\prime \prime} \\
72^{\circ} 59^{\prime} 45^{\prime \prime} \\
72^{\circ} 59^{\prime} 39^{\prime \prime}\end{array}$ \\
\hline
\end{tabular}




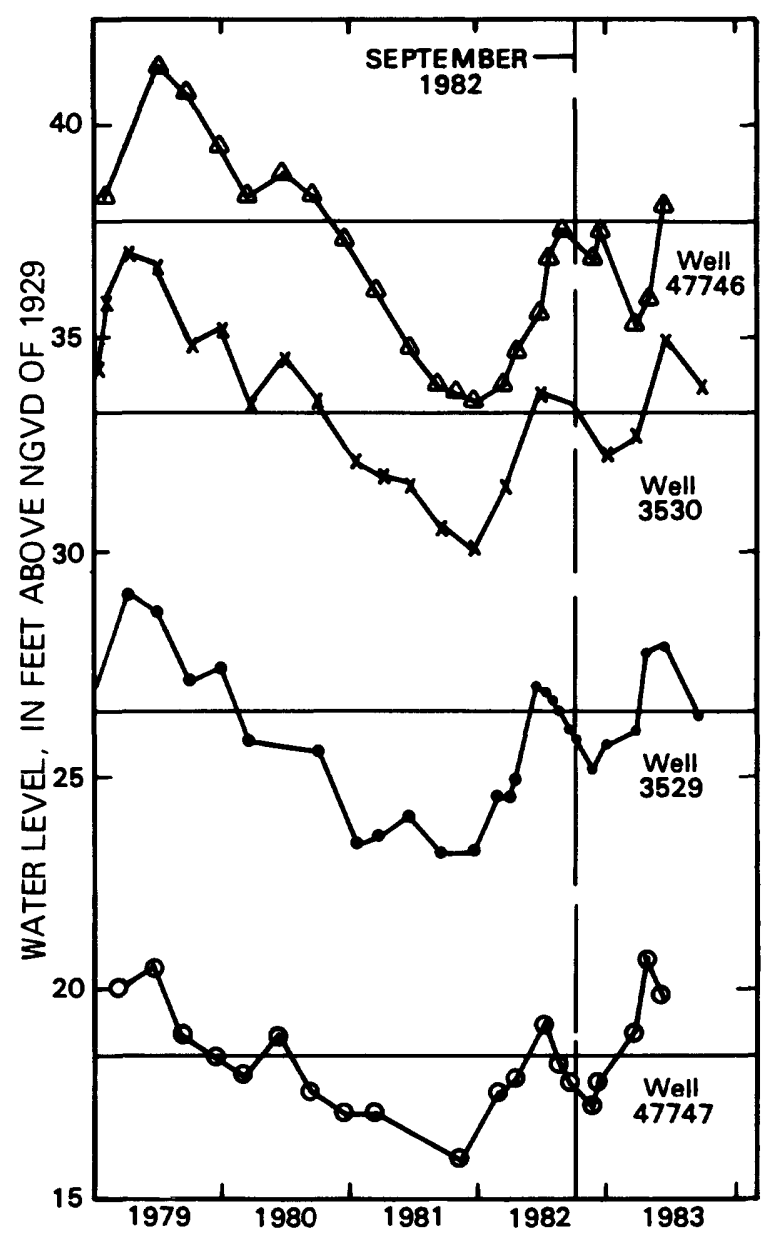

Eigure 7.

Five-year hydrographs of four observation wells in study area, 1979-83. (Horizontal lines indicate 5-year average water level; well locations are shown in $p l$. 1.)

River, respectively. Steep ground-water gradients toward the streams indicate that streamflow accounts for most of the ground-water discharge from the study area. Other factors that may affect water-table gradients are (1) heterogeneity of the aquifer material, (2) pumpage for public supply and domestic uses, (3) recharge from sewage-treatment plants and other sources of recharge and redistribution of pumped water, and (4) local variations in the rates of recharge and leakage through the clay units underlying the upper glacial aquifer.

\section{Ground Water in the Magothy Aquifer}

The Magothy aquifer is confined by the Gardiners Clay and Monmouth greensand in most of the study area; silt and clay within the upper part of the Magothy also tend to confine water in the more permeable basal part of the aquifer. The general direction of ground-water movement in the Magothy aquifer is shown in cross section in figure $6(\mathrm{p}, 12)$.

A potentiometric-surface map of the Magothy aquifer in the study area was prepared from available water-level data and is shown in figure 8 . The major component of flow in the Magothy aquifer is toward the south shore, where discharge is upward through the overlying clays and into the upper glacial aquifer. 


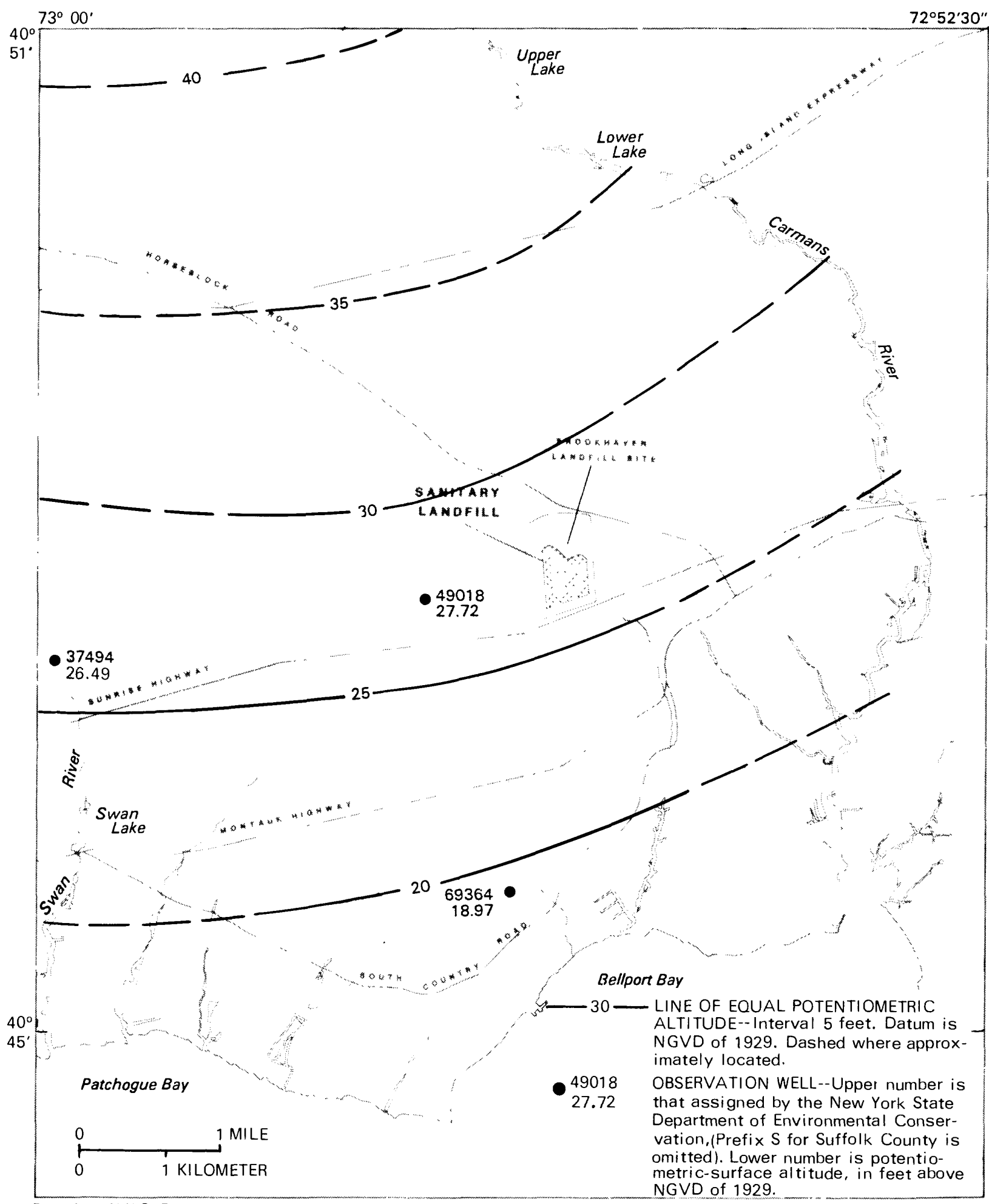

Base from N.Y.S. Department of Transportation,

Bellport, 1981: Howells Point, 1981, NY, 1:24,000

Figure 8.--Potentiometric surface of Magothy aquifer in study area, September 1982. 
Comparison of water levels in the upper glacial aquifer with potentials in the Magothy aquifer ( $\mathrm{p} 1.2$ and $\mathrm{fig}$. 8) shows that most recharge to the Magothy is in the northern part of the study area (north of the Brookhaven landfill site), where heads in the upper glacial aquifer exceed those in the Magothy. Discharge from the Magothy aquifer occurs in the southern part of the study area, where heads in the Magothy aquifer exceed those in the upper glacial aquifer. The boundaries of the zones of recharge and discharge are not fixed but constantly shift in response to head changes in both aquifers.

\section{Water Budget}

A water budget is an accounting of all inflows, outflows, and changes in storage within a given area. A steady-state water budget that does not consider changes in ground-water storage was developed for the study area to obtain estimates of the rates of (1) ground-water inflow through the northern boundary of the area, (2) subsurface discharge along the shore, and (3) leakage through the confining units that separate the upper glacial aquifer and the Magothy aquifer.

The area considered in the water-budget analysis is indicated in figure 9; it extends north of the study area to the regional ground-water divide (fig. 1). The regional ground-water divide in the upper glacial aquifer was assumed to correspond with that in the underlying Magothy aquifer. The southern boundary of the water-budget area is the freshwater/saltwater interface, which lies close to the shore of Patchogue and Bellport Bays in the upper glacial aquifer and beneath the barrier islands to the south in the Magothy aquifer (fig. 6).

The western boundary of the water-budget area is the Swan River and a flow line extended northward from the start-of-flow to the regional ground-water divide. The eastern boundary is the lower reach of the Carmans River (south of Lower Lake) and a line extended northward from the downstream end of Lower Lake to the regional ground-water divide. (The eastern boundary was drawn this way to include ground water that may pass beneath the shallow flow system associated with the upper reaches of Carmans River and flows southward into the study area.) The bottom boundary of the water-budget area is the upper surface of the Raritan clay. Leakage through the Raritan clay into the Lloyd aquifer probably constitutes less than 1 percent of the total recharge to the water-budget area and, therefore, was not included in the water-budget analyses.

A schematic diagram showing inflows and outflows from the area is given in figure 10. Values of inflows and outflows were calculated from best estimates of aquifer and confining-unit properties and recharge rates discussed in previous sections. The rate of inflow across the northern boundary of the model area is estimated to be $12 \mathrm{ft}^{3} / \mathrm{s}$, and net leakage into the upper glacial aquifer from the lagothy is estimated to be $17 \mathrm{ft}^{3} / \mathrm{s}$. Although these values may be in error because of uncertainties in aquifer properties, this analysis provides a reasonable estimate of inflows to and discharge from the study area. These estimates were used in the development of a ground-water flow model representing the study area and refined during model calibration. 


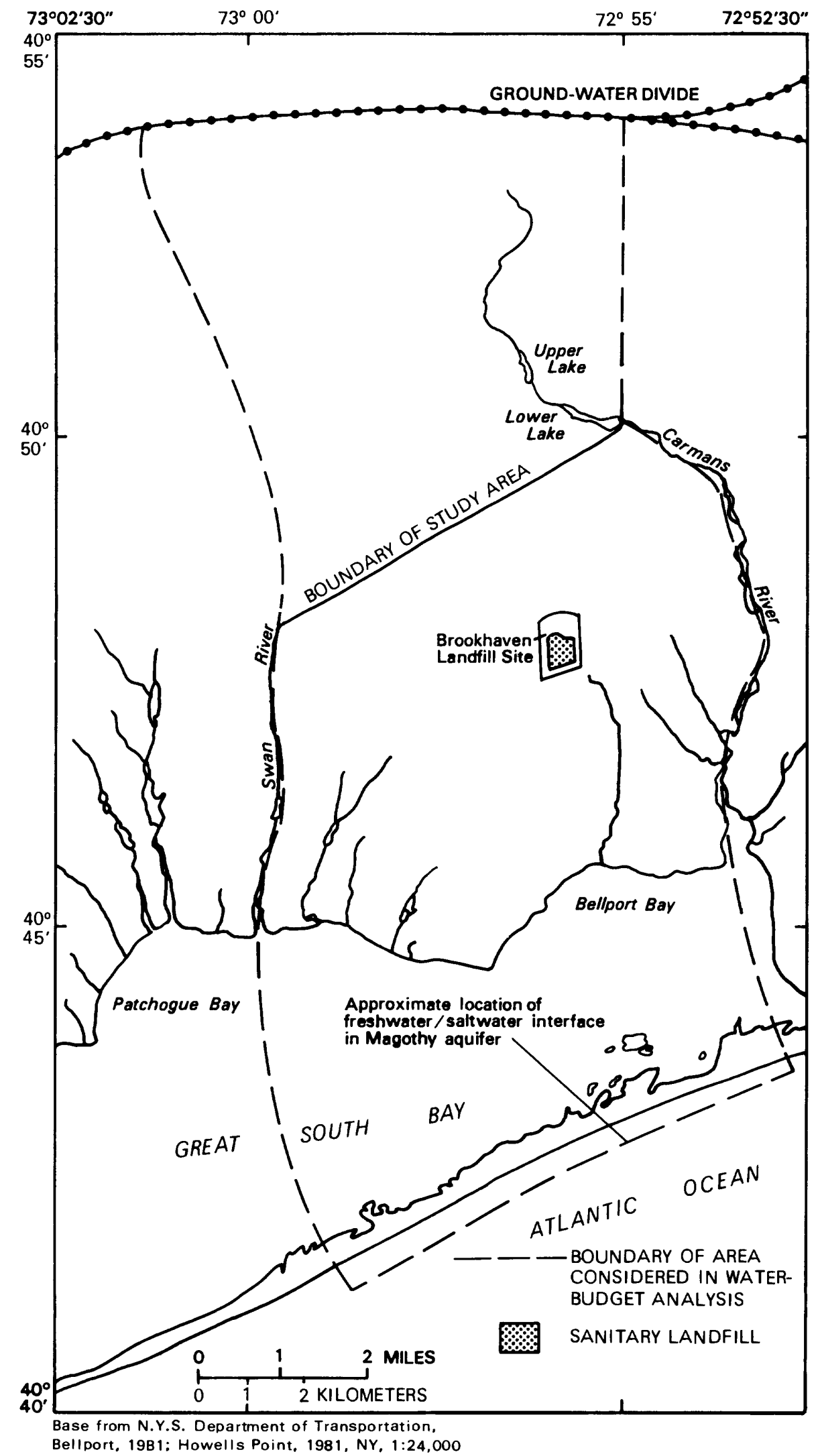

Figure 9.--Area considered in water-budget analysis. (Location is shown in fig. 1.) 


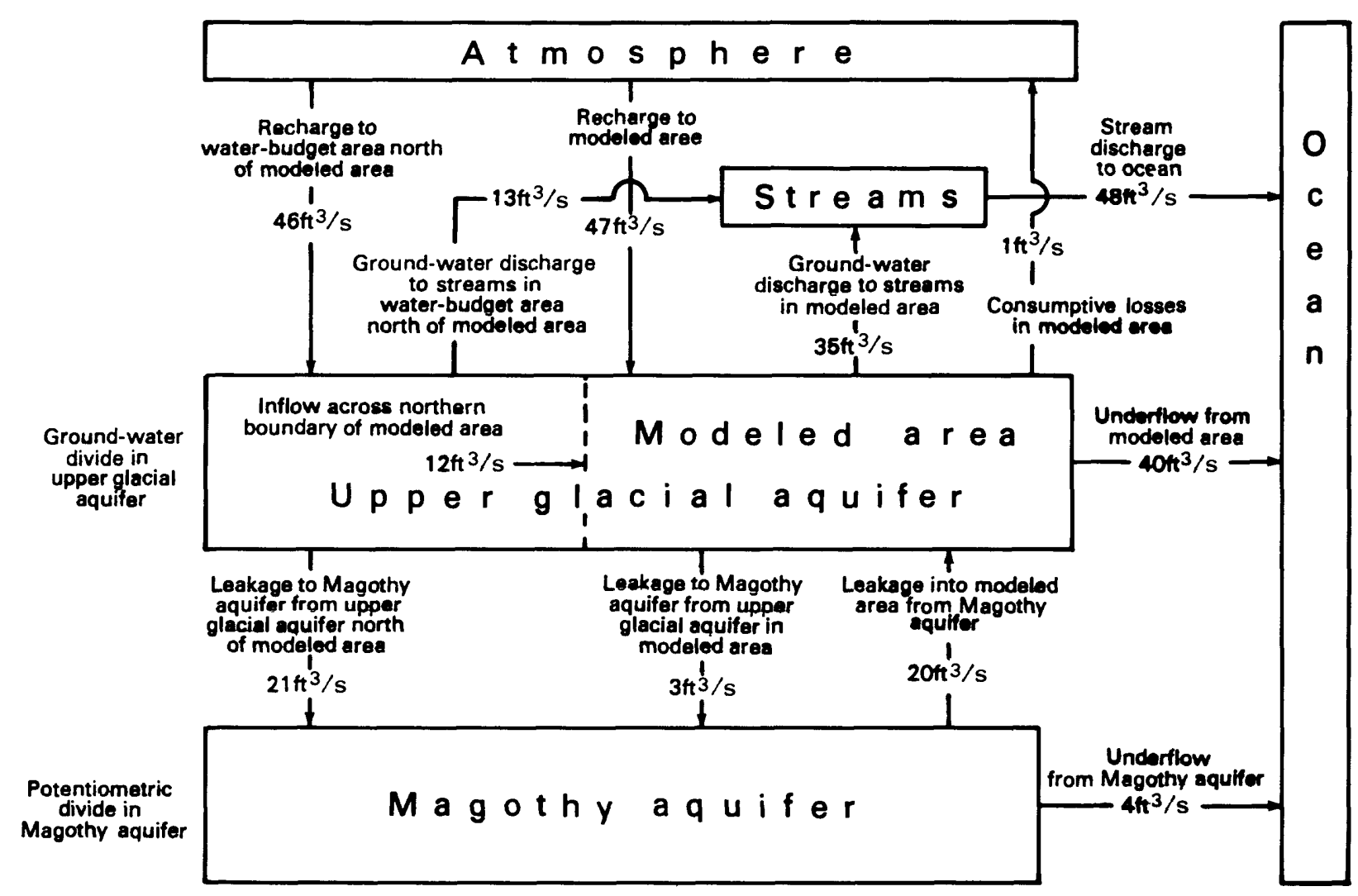

Figure 10.--Components and rates of flow in water-budget area as determined from water-budget analysis.

\section{SIMULATION OF GROUND-WATER FLOW}

A digital model was developed from the hydrogeologic data discussed previously to simulate steady-state ground-water flow in the study area. The model represents the upper glacial aquifer and allows for steady leakage of ground water through the Gardiners Clay. Flow in the upper glacial aquifer is assumed to be horizontal.

Estimates of aquifer and confining-unit properties and the rates of flow across model boundaries were refined through the process of model calibration. Once calibrated, the model was used to calculate rates and directions of ground-water flow within the Brookhaven landfill site and vicinity. A brief discussion of the ground-water flow equation, types of boundary conditions, and assumptions used in the model is given below.

\section{Theoretical Background}

The partial differential equation governing steady-state two-dimensional (areal) ground-water flow in a heterogeneous, isotropic water-table aquifer is given by Bear (1979, p. 121) as: 


$$
\frac{\partial}{\partial x}\left[K(h-b) \frac{\partial h]}{\partial x}+\frac{\partial}{\partial y}\left[K(h-b) \frac{\partial h]}{\partial y}+N-W=0\right.\right.
$$

where: $K=$ hydraulic conductivity at a point in the aquifer [LT-1],

$\mathrm{h}=$ hydraulic head (or water-table altitude) above a datum [L],

$b=$ altitude of aquifer bottom above the same datum [L],

$\mathrm{N}=$ rate of areal recharge per unit area of aquifer [LT $\left.{ }^{-1}\right]$, and

$W=$ rate of withdrawal from the aquifer per unit area $\left[\mathrm{LT}^{-1}\right]$.

Two simplifying assumptions are implicit in this form of the equation:

(1) Flow in the aquifer is horizontal; that is, the slope of the water table is small enough that equipotential lines are nearly vertical (referred to as the Dupuit assumption). Also, vertical flow components near streams and partially penetrating wells and near the base of the aquifer where vertical leakage may be occurring are assumed to have negligible effects on regional flow in the aquifer.

(2) The density of the water is uniform, and gradients induced by concentration or temperature differences are assumed to have negligible effects on regional flow.

Three types of boundary conditions are associated with equation 1. The first type, referred to as a prescribed head (or Dirichlet) boundary condition, is defined by:

$$
\mathrm{h}=\mathrm{H}_{1}
$$

where $h$ is the head in the aquifer at a point on the boundary, and $\mathrm{H}_{1}$ is a known value. The second type, referred to as a prescribed flux (or Neumann) boundary condition, is defined by:

$$
\mathrm{q}_{\mathrm{n}}=\mathrm{Q}_{1}
$$

where $q_{n}$ is the rate of flow normal to the boundary, and $Q_{1}$ is a known value. A no-flow boundary, in which $Q_{1}$ is equal to zero, is used to represent streamline or impermeable boundaries. The third type, referred to as a head-dependent flux (or Cauchy) boundary condition, is applied where the flow across the aquifer boundary is dependent on the difference between the head in the aquifer and a known head on the opposite side of a semipervious layer. The head-dependent flux boundary condition is defined by:

$$
\mathrm{q}_{n}=\frac{\mathrm{K}^{\prime}\left(\mathrm{H}_{\mathrm{o}}-\mathrm{h}\right)}{\mathrm{B}^{\prime}}
$$

where: $q_{n}=$ the boundary flux $\left[\mathrm{LT}^{-1}\right]$,

$\mathrm{K}^{\prime}=$ hydraulic conductivity of the semipervious layer [LT' $\left.{ }^{-1}\right]$,

$B^{\prime}=$ thickness of the semipervious layer [L],

$\mathrm{h}=$ head in the aquifer [L], and

$\mathrm{H}_{\mathrm{O}}=$ known head on the opposite side of a semipervious layer [L].

Additional theoretical discussions on the ground-water flow equation and boundary conditions can be found in Bear (1979, p. 117-123). 
Equation 1 is nonlinear and can be solved analytically only for idealized conditions. For areas with irregularly shaped boundaries or with spatial variation in aquifer properties, numerical methods must be used. These methods involve finding a solution for the head values at a selected number of points within the area modeled rather than at all points. One technique, called the Galerkin finite-element method, involves dividing a map of the area modeled into a grid composed of smaller areas termed elements. For twodimensional problems, the elements can be triangles, rectangles, or quadrilaterals. Points at the junctions of lines on the finite-element grid are termed nodes. Given appropriate boundary conditions, an approximation of the true water-table configuration can be determined by solving equation 1 for each node in the finite-element grid.

The Galerkin finite-element method has been applied extensively in the simulation of ground-water flow. Discussions on the theory and application of the method are given in Pinder and Gray (1977), Wang and Anderson (1982), Bear (1979), and Remsen and others (1971). Several computer codes that use the finite-element method are available for a wide range of problems in subsurface hydrology. The computer code used in this study was originally developed by J. V. Tracy of the U.S. Geological Survey. Modifications made to the original code by J. V. Tracy and E. J. Wexler are documented in a report by Dunlap and others (1984). The computer code uses triangular or isoparametric quadrilateral elements with linear basis functions; element integrations are done numerically with a 4-point Gaussian quadrature technique, and the simultaneous equations generated are solved by the Cholesky decomposition method for symmetrical matrices (Dunlap and others, 1984).

Two changes to the code described by Dunlap and others (1984) were made in this study. The first relates to the method used to treat the nonlinear terms in equation $1, K(h-b) \partial h / \partial x$ and $K(h-b) \partial h / \partial y$. An iterative procedure is used to solve for $h$ (the water-table altitude) rather than the perturbation method used in the code described by Dunlap and others (1984).

In the iterative procedure, values for the term $k(h-b)$, which represents the effective transmissivity of the water-table aquifer, are first calculated from the initial values for the water levels. Equation 1 is solved, and the new water-table altitudes are then used to recalculate the effective transmissivity term. The procedure is repeated until a convergence criterion is met. This iterative procedure is also described in Pinder and Gray (1977) and Bear (1979).

A second change relates to the method used to simulate ground-water seepage to streams and is described in a subsequent section.

\section{Model Design}

In the model, the upper glacial aquifer is represented as a single layer, and flow is assumed to be horizontal. The upper boundary of the area modeled is defined by the water table, and the lower boundary is the base of the upper glacial aquifer except in the nearshore area, where the lower boundary is defined by the freshwater/saltwater interface. 
The study area is represented by a fintte-element grid composed of 2,490 quadrilateral elements with 2,604 nodes. The lateral boundaries of the grid (fig. 11) approximate those of the study area. The grid is finer in the center of the study area to provide the necessary detail at and near the 1 andfill site.

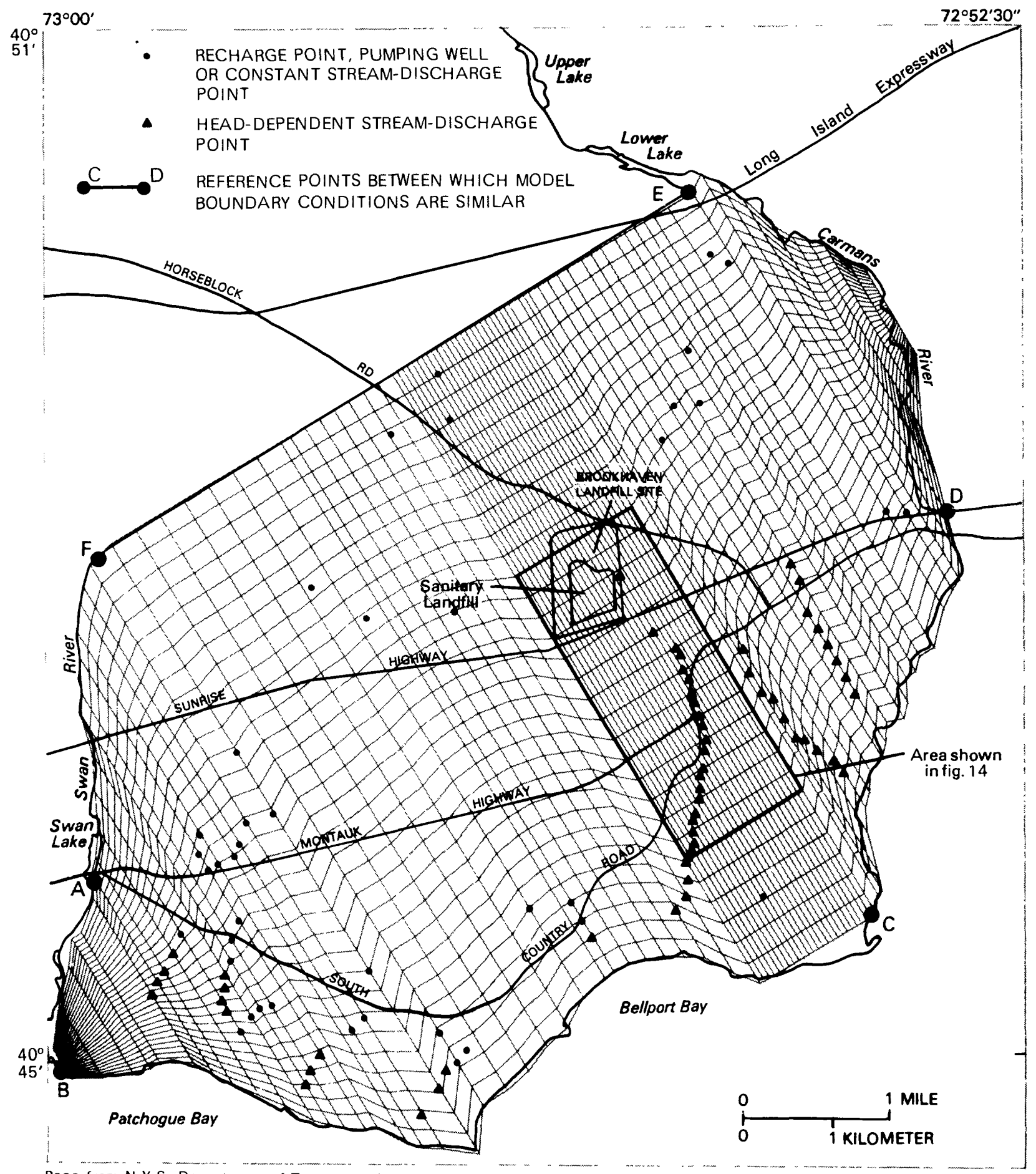

Base from N.Y.S. Department of Transportation,

Bellport, 1981: Howells Point, 1981, NY, 1:24,000

Figure 11.--Finite-element grid used to represent the study area. 


\title{
Application of Boundary Conditions
}

\author{
Prescribed-Head Boundaries
}

\begin{abstract}
Prescribed-head boundary conditions (eq. 2) were applied to all nodes representing the lateral boundaries of the study area. Although net rates of flow across these boundaries had been estimated in the water-budget analysis, prescribed-flux boundaries (eq. 3) were not used because the distribution of fluxes at nodes along the boundary is not uniform and could not be easily calculated. Boundary fluxes at the prescribed-head boundaries, which are very sensitive to changes in the values of aquifer properties, were calculated by the computer code and compared with streamflow data and estimated flow rates across the northern and shore boundaries during model calibration.
\end{abstract}

Prescribed-head values at nodes along the the shore and tidal reaches of the Swan and Carmans Rivers (line ABCD in fig. 11) were set equal to zero to represent sea level. Prescribed-head values at nodes along the northern boundary of the study area (line E-F in fig. 11) were determined from September 1982 water-table altitudes (p1. 2).

The Carmans River is ponded for most of its length between Lower Lake and the tidal reach (1ine D-E in fig. 11) behind the three manmade controls in Southhaven Park (p1. 1). Prescribed-head values for nodes along ponded reaches were set to surface-water altitudes of September 1982. Prescribedhead values for nodes between ponded reaches were obtained by interpolation from topographic maps.

Nodes representing the Swan River (1ine A-F in fig. 11) were treated similarly. Nodes along Swan Lake were assigned prescribed-head values equal to September 1982 surface-water altitudes, and prescribed-head values at nodes between the start-of-flow and Swan Lake were obtained from two staff gages on the Swan River (stations $S R 1$ and $S R 2$ ) and by interpolation from topographic maps.

Nodes representing Dunton Lake, Robinson Pond, the upper ponded reach of Little Neck Run, and a pond near Sunrise Highway in Southaven Park (fig. 2) were treated as internal prescribed-head nodes. Prescribed-head values were set equal to September 1982 surface-water altitudes. Nodes on the broad tidal reaches of Mud Creek and Abets Creek (fig. 2) were also treated as prescribedhead nodes with head values set equal to zero.

\section{Head-Dependent Flux Boundary}

The base of the upper glacial aquifer was selected as the lower boundary of the modeled area except in the nearshore area. A head-dependent flux boundary condition (eq. 4) was used to represent this boundary and account for steady leakage across the confining units (Gardiners Clay and Monmouth greensand) underlying the upper glacial aquifer. Values for the thickness of the confining units were determined by interpolation from the contours in figure 4 and were specified at each node in the finite-element grid. A uniform value of $2.9 \times 10^{-3} \mathrm{ft} / \mathrm{d}$, based on published values, was initially specified for the hydraulic conductivity of the confining units but was adjusted during model calibration. 
Prescribed-head values in the llagothy aquifer were interpolated from the potentiometric-surface map depicted in figure 8. Heads in the llagothy aquifer were assumed to remain constant and were not affected by changes in the simulated water-table altitudes in the upper glacial aquifer. During model calibration, net leakage through the confining units was calculated by the computer code and compared with estimates obtained in the water-budget analysis.

\section{Prescribed-Flux Boundaries}

Recharge boundary.--The water table is the upper boundary of the modeled area and was represented by a prescribed-flux boundary. Flow across the prescribed-flux boundary is equal to the annual average rate of recharge to the upper glacial aquifer. As stated in a previous section, annual precipitation in the study area averages $47.4 \mathrm{in} / \mathrm{yr}$. Recharge to the upper glacial aquifer (the amount of precipitation minus the average amount of evapotranspiration and surface runoff) was set equal to 52 percent annual precipitation value $(24.6 \mathrm{in} / \mathrm{yr}$ or $0.056 \mathrm{ft} / \mathrm{d}$ ) and was applied uniformly over the modeled area. Ground-water discharge from the area through ground-water evapotranspiration was assumed to be minor and was not incorporated into the mode1.

Freshwater-saltwater interface.--As in most coastal aquifers, a freshwater-saltwater interface is present within the upper glacial aquifer near the shore, where freshwater in the upper glacial aquifer meets denser, salty ground water underlying Patchogue and Bellport Bays (fig. 6). The interface can be represented as a streamline or no-flow boundary because freshwater discharging to the bay tends to flow along, not through, the interface.

The saltwater-freshwater interface was used to define the lower boundary of the model in the nearshore area. The actual position of the interface is unknown but can be approximated by the Ghyben-Herzberg principle on the assumption that the interface is stationary and that freshwater flow in the aquifer is horizontal (Bear, 1979). The altitude of the bottom of the freshwater zone below sea level ("b" in eq. 1) is given by:

$$
b=\frac{-\rho_{f} \cdot h}{\left(\rho_{s}-\rho_{f}\right)}
$$

where: $\rho_{f}=$ freshwater density, assumed equal to $1.0 \mathrm{~g} / \mathrm{cm}^{3}$;

$\rho_{s}=$ saltwater density; and

$\mathrm{h}=$ simulated water-table altitude (above sea level) at a node.

A value of $1.015 \mathrm{~g} / \mathrm{cm}^{3}$ for $\rho_{\mathrm{s}}$ was used in the Long Island regional mode 1 (D. A. Snolensky, U.S. Geological Survey, oral commun., 1984) and was found to produce reasonable results in the study-area model. The toe of the interface is the point at which the value for b equals the altitude of the base of the upper glacial aquifer. Landward of that point, the head-dependent flux boundary condition is applied as described in the preceding section. A minimum freshwater thickness of $20 \mathrm{ft}$ was used to represent the outflow face seaward of the shore, where freshwater discharges directly to the bay (fig. 6). 


\section{Aquifer Properties}

Values for hydraulic conductivity and basal altitudes of the upper glacial aquifer were specified at each node in the finite-element grid. Altitudes of the aquifer bottom were interpolated from the base-configuration map shown in figure 5. A uniform hydraulic conductivity was assumed for the upper glacial aquifer because the aquifer testing and lithologic data did not indicate any systematic variation in this property. The hydraulic conductivity was initially set equal to $267 \mathrm{ft} / \mathrm{d}$ at all nodes in accordance with previously published estimates (McClymonds and Franke, 1972) and was adjusted during model calibration.

\section{Points of Recharge and Discharge}

All points of recharge or discharge within the study area were represented as fully penetrating wells. If the source of recharge or discharge was near a node in the finite-element grid, the full value of the recharge or discharge was applied to the node. If not, a percentage of the flow was allocated to each of the four nodes that form the element in which the source was located, as described in Segerlind (1976). The former method is preferred, especially if the elements are large, but the grid was not designed to have nodes at all points of recharge or discharge.

\section{Pumpage and Redistribution of Ground Water}

The locations and annual discharges from public supply and industrial pumpage sites are listed in table 5. The largest redistribution of withdrawn water is the discharge of treated water from sewage-treatment plants to ground water. Locations of the treatment plants are shown on plate 1, and discharge rates are given in table 3. Rates of pumpage and redistribution vary seasonally, but average annual rates were specified for the steady-state simulation.

\section{Ground-Water Discharge to Streams}

The study area contains eleven shallow streams, including the Carmans and Swan Rivers, as described earlier. Estimates of annual average base flow in streams with continuous or partial-discharge measurements are given in table 4 .

Ground-water discharge to streams in the steady-state model was simulated by a line of discharge points. The discharge at each point was calculated by one of several methods, depending on the amount of data available. The calculated discharge was allocated to model nodes by the same method as for points of pumpage or redistribution.

The rate of ground-water discharge at each point on all gaged streams except Beaverdam Creek, Little Neck Run, and Yapahank Creek was calculated by dividing the average increase in flow along a gaged reach by the number of discharge points used to represent the reach. The discharge at points representing ungaged streams were extrapolated from base-flow data on the 
nearest gaged stream. The calculated rates of ground-water discharge were not varied for either type of stream during model calibration.

Ground-water seepage to points representing Beaverdam Creek, Little Neck Run, and Yapahank Creek, the streams closest to the landfill site, was simulated in the model as head-dependent discharge. A similar method of simulating discharge to streams was used in the Long Island regional model and is discussed by Harbaugh and Getzen (1977) and Reilly and others (1983). Increases in streamflow over a gaged reach can be more accurately distributed to each discharge point because this method incorporates data on stream geometry, average stream-surface altitudes, and aquifer heads.

The ground-water discharge at each point was determined by:

$$
Q=\frac{\mathrm{K}_{\mathrm{sb}} \cdot \mathrm{A}_{\mathrm{s}} \cdot\left(\mathrm{h}-\mathrm{H}_{\mathrm{s}}\right)}{\mathrm{B}_{\mathrm{sb}}}
$$

where: $\mathrm{K}_{\mathrm{Sb}}=$ vertical hydraulic conductivity of the streambed material [L/T]; $\mathrm{B}_{\mathrm{sb}}=$ average thickness of the streambed [L];

$A_{S}=$ area of the stream, equal to the length of the reach multiplied by its average width $\left[\mathrm{L}^{2}\right]$;

$\mathrm{h}=$ simulated head in the aquifer [L]; and

$\mathrm{H}_{\mathrm{S}}=$ average stream-surface altitude above sea level [L].

The vertical hydraulic conductivity of streambed material was initially set equal to $6.5 \mathrm{ft} / \mathrm{d}$, and the average streambed thickness was assumed to equal $3.0 \mathrm{ft}$. Streambed hydraulic conductivity was varied during model calibration, and simulated streamflow in each reach was checked against the estimated average base-flow values presented in table 4 .

Ground-water discharge to tidal reaches of streams in the study area has not been measured. To obtain estimates of discharge to these reaches, seepage to the tidal reaches of all streams was simulated as head-dependent discharge. Average stream-surface altitudes in the tidal reaches were set equal to sea level or interpolated from available stream-surface-altitude data. Vertical hydraulic conductivity of the streambed material was initially set equal to $6.5 \mathrm{ft} / \mathrm{d}$ and was adjusted during calibration of the model.

\section{Model Calibration}

Model calibration was done through a trial-and-error procedure in which aquifer and confining-unit properties were adjusted until a reasonable match between the simulated water-table altitudes and the water-table configuration in September 1982 ( $p 1.2$ ) was obtained. A "least-squares" method, in which simulated and observed water-table altitudes at 93 observation wells in the area were compared, was used as a means of determining the best fit. Streamflows and flows across the model boundaries were calculated and checked against estimates obtained in the water-budget analysis as part of the calibration procedure. Initial estimates of aquifer and confining-unit hydraulic conductivity used in the model are given in table 7 along with the final values obtained through model calibration. 
Table 7..-Initial and final values of hydraulic conductivity used in steady-state flow model.

[All values are in $\mathrm{ft} / \mathrm{d}$ ]

\begin{tabular}{ccc}
\hline Material & Initial estimate & Final value \\
\hline $\begin{array}{c}\text { Upper glacial aquifer } \\
\text { Streambed material in } \\
\text { flowing reaches }\end{array}$ & 267 & 200 \\
$\begin{array}{c}\text { Streambed material in } \\
\text { tidal reaches }\end{array}$ & 6.50 & 6.50 \\
\begin{tabular}{c} 
Confining unit ${ }^{2}$ \\
\hline
\end{tabular} & $2.9 \times 10^{-3}$ & 3.25 \\
\hline
\end{tabular}

1 Streambed thickness assumed to equal $3.0 \mathrm{ft}$.

2 Gardiners Clay and Monmouth greensand, where present.

\section{Simulated Water-Table Altitudes}

The simulated water-table altitudes were contoured by a graphics routine developed in this study and are presented in figure 12 . The computer code was used to calculate the differences between the water-table altitudes observed in September 1982 and simulated values at the locations of 93 observation wells. The average difference was $0.59 \mathrm{ft}$, with a standard deviation of 0.82 . The maximum difference was equal to $2.6 \mathrm{ft}$ at well $\mathrm{s} 72128$ (we11 location shown in $\mathrm{p} 1.1$ ).

Comparison of the simulated with the observed water-table altitudes (also shown in fig. 12) shows that the water levels match closely over the entire study area; the best match is in the center of the study area. The greatest differences are in the southwestern part of the study area, where the simulated values are 1 to $3 \mathrm{ft}$ lower than the observed values.

A better match might be obtained by adjusting hydraulic conductivity values over different parts of the modeled area, but the hydrologic data, particularly aquifer-test data, needed for a distribution of values are lacking. These data and additional measurements of the potentiometric surface of the Magothy aquifer, thickness of the clay units, and aquifer-base altitude would increase the knowledge of the hydrogeology of the area and could improve the accuracy of the model.

\section{Simulated Water Budget}

As part of the calibration procedure, flows across all prescribed head and leakage boundaries were calculated. The flows obtained from the calibrated model are given in table 8; a schematic diagram presenting a revised water-budget analysis based on the simulated flows is given in 


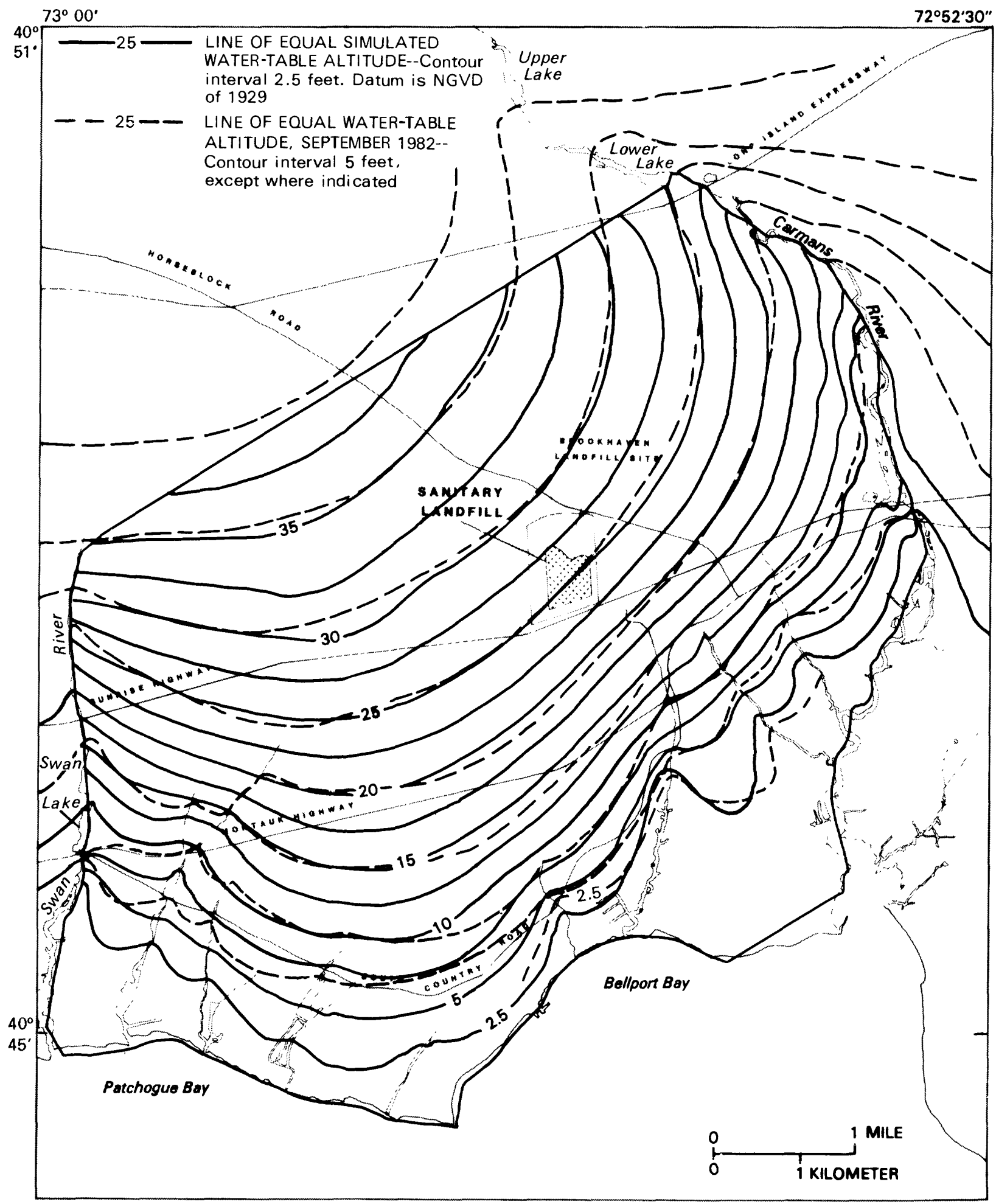

Base from N.Y.S. Department of Transportation,

Bellport, 1981; Howells Point, 19B1, NY, 1:24,000

Figure 12.--Simulated and observed (September 1982) water-table configuration. 
figure 13. The simulated flows compare favorably with the values obtained through the initial water-budget analysis (fig. 10), although some differences are evident, primarily in the rates of leakage through the confining units.

Table 8.--Simulated inflows to and discharges from the study area. [All values are in cubic feet per second]

\begin{tabular}{lr} 
INFLOWS & Flow rate \\
& \\
Recharge from precipitation & 47.31 \\
Underflow at northern boundary & 9.84 \\
Upward leakage 1nto upper glacial aquifer & 23.40 \\
Recharge from sewage-treatment plants & 1.70 \\
DISCHARGES & \\
& \\
Discharge at shore boundaryl & 21.01 \\
Downward leakage from upper glacial aquifer & 5.42 \\
Withdrawal at public-supply and industrial wells & 3.11 \\
Discharge to the Swan River & 5.15 \\
Discharge to the Carmans River & 12.61 \\
Discharge to streams within the study area & 15.39 \\
Discharge to tidal reaches of streams & 19.45 \\
Discharge to internal prescribed-head nodes 2 & 0.11 \\
\hline & \\
I Includes discharge to tidal reaches of the Swan and \\
Carmans Rivers. \\
Includes Dunton Lake, Robinson's Pond, the upper ponded \\
reach of Little Neck Run, and a pond near Sunrise Highway \\
in Southhaven Park (shown in pl. 1).
\end{tabular}

\section{Ground-Water Velocities Near the Brookhaven Landfill Site}

Once the ground-water flow model was calibrated, it was used to calculate directions and rates of ground-water flow in the vicinity of the landfill site. The average ground-water velocity (v) can be calculated from Darcy's law as:

$$
\mathrm{v}=\frac{\mathrm{Ki}}{\mathrm{n}}
$$

where: $\mathrm{K}=$ aquifer hydraulic conductivity $[\mathrm{L} / \mathrm{T}]$,

$i=$ hydraulic gradient as indicated by the slope of the water table [dimensionless], and

$\mathrm{n}=$ effective porosity of the aquifer material [dimensionless].

A scaled vector plot of velocities at the midpoint of elements in the area downgradient from the landfill site (area indicated in fig. 11) is shown in figure 14A. Velocities were calculated from a hydraulic conductivity of 


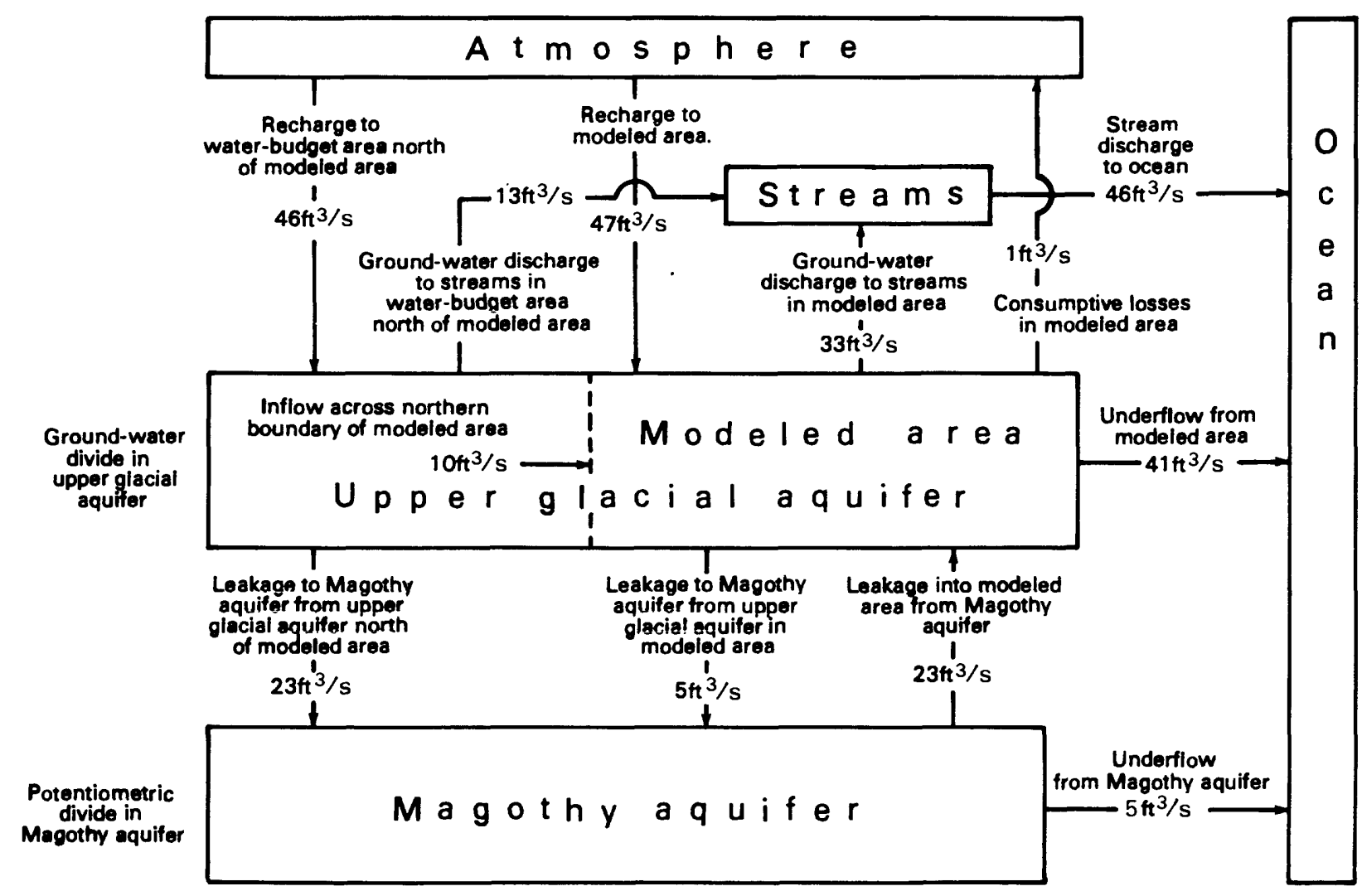

Figure 13.--Components and rates of flow in water-budget area as determined by calibrated model. (Compare estimated values, fig. 10.)

$200 \mathrm{ft} / \mathrm{d}$ and an effective aquifer porosity of 0.30 . Average ground-water velocities in this area ranged from 0.2 to $4.4 \mathrm{ft} / \mathrm{d}$. The computed velocity at the center of the landfill site is equal to $1.1 \mathrm{ft} / \mathrm{d}$ in the direction $544^{\circ} \mathrm{E}$.

Flow lines downgradient from the site are plotted in figure 14B. These lines provide a general indication of paths that would be followed by contaminants entering ground water beneath the sanitary landfill. The flow lines can illustrate only the advective movement of ground water, however. Dispersive mixing, which causes the spreading of contaminants along and transverse to the flow lines, would need to be evaluated before the movement of contaminants from the sanitary landfill could be accurately predicted.

A second model was developed with data generated by this flow model. This model was used to simulate advective-dispersive transport of conservative solutes from the landfill site and is described in part 3 of this series (Wexler, 1987b). 

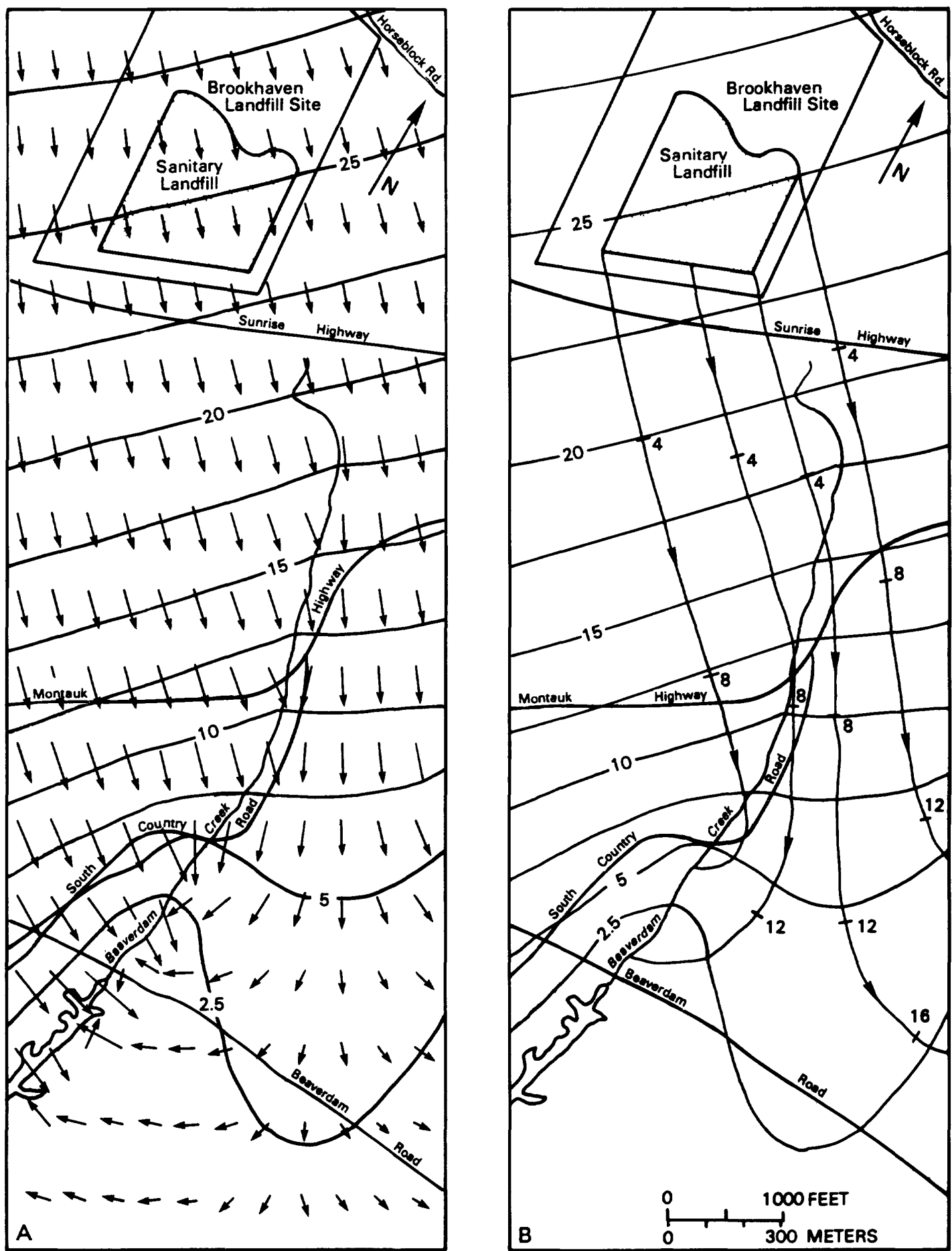

Base from N.Y.S. Department of Transportation, Bellport, 1981; Howells Point, 1981, NY, 1:24,000

$$
\text { EXPLANATION }
$$

SCALED GROUND-WATER-VELOCITY VECTOR 8 DIRECTION OF GROUND-WATER FLOW--Number is approximate travel time
from landfill to indicated point, in years.

$10-$ LINE OF EQUAL WATER-TABLE ALTITUDE (SIMULATED), SEPT. 1982--

Contour interval 2.5 feet. Datum is NGVD of 1929

Figure 14.--Simulated ground-water velocity $(A)$ and direction of ground-water flow ( $B$ ) in upper glacial aquifer downgradient from Brookhaven landfill site. (Location of area is shown in fig. 11.) 


\section{SUMMARY AND CONCLUSIONS}

The hydrogeology of a $26-\mathrm{mi}^{2}$ area surrounding the Brookhaven landfill site was studied as a preliminary step in the investigation of solute transport from the site. Hydrogeologic information from previous investigations and field data gathered in this study were used to describe the groundwater flow system, delineate the hydrologic boundaries of the area, and provide initial estimates of aquifer and confining-unit properties. Well logs from public-supply wells and from geologic test holes provided data on the extent and thickness of the confining units that separate the upper glacial aquifer from the underlying Magothy aquifer.

Precipitation is the major source of recharge to the upper glacial aquifer in the study area. Additional sources of recharge include underflow across the northern boundary of the study area and upward leakage through the confining units.

Ground water is discharged from the upper glacial aquifer as seepage to streams, outflow at the shore to Bellport and Patchogue Bays, downward leakage to the Magothy aquifer in the northern part of the area, and pumpage for agricultural use and public and domestic supply. Most of the pumped water is returned to the aquifer close to the point of withdrawal as irrigation return flow or discharge from cesspools and septic tanks. The most significant redistribution of pumped water is the discharge of water from sewage-treatment plants to ground water.

A water-table map for September 1982 (p1. 2) was prepared from data gathered from a network of 164 observation wells and 23 stream-stagemeasurement sites. The water-table map represents a period of average water levels in the upper glacial aquifer.

A two-dimensional finite-element model of the study area was developed to simulate steady-state ground-water levels in the upper glacial aquifer under average conditions. The model was callbrated by adjusting hydrologic values until the simulated water levels matched those observed in September 1982 and simulated flows across the model boundaries compared favorably with estimates calculated in a water-budget analysis. The steady-state water-table altitudes generated by the calibrated model were then used to compute the ground-water velocity in the landfill-site vicinity. The velocity at the center of the site, based on an average aquifer porosity of 30 percent, is $1.1 \mathrm{ft} / \mathrm{d}$ with a bearing of $544^{\circ} \mathrm{E}$. A solute-transport model developed from data obtained in this study is described in the third report in this series (Wexler, 1987b); additional data on hydrogeologic conditions and ground-water quality in the site vicinity are given in part 1 (Wexler, 1987a). 


\section{REFERENCES CITED}

Bear, Jacob, 1979, Hydraulics of ground water: New York, McGraw Hill, 569 p.

Cohen, Philip, Franke, 0. L., and Foxworthy, B. L., 1968, An atlas of Long Island's water resources: New York State Water Resources Commission Bulletin 62,117 p.

de Laguna, Wallace, 1963, Geology of Brookhaven National Laboratory and vicinity, Suffolk County, New York: U.S. Geological Survey Bulletin 1156-A, $35 \mathrm{p}$.

Donaldson, C. D., and Koszalka, E. J., 1983a, Potentiometric surface of the Magothy aquifer, Long Island, New York, in March 1979: U.S. Geological Survey Open-File Report 82-160, 2 sheets, 1:125,000.

1983b, Water table on Long Island, New York, March 1979: U.S. Geological Survey Open-File Report 82-163, 2 sheets, 1:125,000.

Dunlap, L. E., Lindgren, R. J., and Carr, J. E., 1984, Projected effects of ground-water withdrawals in the Arkansas River Valley, 1980-99, Hamilton and Kearny Counties, southwestern Kansas: U.S. Geological Survey WaterResources Investigations Report 84-4082, 168 p.

Franke, 0. L, and Cohen, 1972, Regional rates of ground-water movement on Long Island, New York, in Geological Survey Research, 1972: U.S. Geological Survey Professional Paper 800-C, p. C271-C277.

Franke, 0. L., and McClymonds, N. E., 1972, Summary of the hydrologic situation on Long Island, New York, as a guide to water-management alternatives: U.S. Geological Survey Professional Paper 627-F, 59 p.

Fuller, M. L., 1914, The geology of Long Island, New York: U.S. Geological Survey Professional Paper 82, 231 p.

Getzen, R. T., 1977, Analog-model analysis of regional three-dimensional flow in the ground-water reservoir of Long Island, New York: U.S. Geological Survey Professional Paper 982, 49 p.

Harbaugh, A. W., and Getzen, R. T., 1977, Stream simulation in an analog model of the ground-water system on Long Island, New York: U.S. Geological

Survey Water-Resources Investigations 77-58, $15 \mathrm{p}$.

Jensen, H. M., and Soren, Julian, 1971, Hydrogeologic data from selected wells and test holes in Suffolk County, Long Island, New York: Suffolk County Department of Environmental Control, Long Island Water Resources Bulletin 3, 35 p.

1974, Hydrogeology of Suffolk County, Long Island, New York, U.S. Geological Survey Hydrologic Investigations Atlas HA-501, 2 sheets.

Kimmel, G. E., and Braids, 0. C., 1980, Leachate plumes in ground water from Babylon and Islip landfills, Long Island, New York: U.S. Geological Survey Professional Paper 1085, 38 p. 


\section{REFERENCES CITED (continued)}

Krulikas, R. K., 1981, Hydrogeologic data from selected wells and test holes in Suffolk County, Long Island, New York, 1972-80: U.S. Geological Survey Open-File Report 81-500, 27 p.

McClymonds, N. E., and Franke, O. L., 1972, Water-transmitting properties of aquifers on Long Island, New York: U.S. Geological Survey Professional Paper 627-E, $24 \mathrm{p}$.

Miller, J. F., and Frederick, R. H., 1969, The precipitation regime of Long Island, New York: U.S. Geological Survey Professional Paper 627-A, 27 p.

Nakao, J. H., and Erlichman, F. R., 1978, The water table on Long Island, New York, in March 1975: U.S. Geological Survey Open-File Report 78-569, $10 \mathrm{p}$.

Padar, F. V., 1983, Investigation of ground-water contamination from municipal landfills, Nassau County, New York: New York Water Pollution Control Association annual meeting, January 1983, $18 \mathrm{p}$.

Pinder, G. F., Gray, W. G., 1977, Finite-element simulation in surface and subsurface hydrology: New York, Academic Press, 259 p.

Pluhowski, E. J., and Kantrowitz, I. H., 1964, Hydrology of the Babylon-Islip area, Suffolk County, Long Island, New York: U.S. Geological Survey Water-Supply Paper 1768,119 p.

Prince, K. R., 1976, The potentiometric surface of the Magothy aquifer on Long Island, New York, in March 1975: U.S. Geological Survey Open-File Report 76-536, $12 \mathrm{p}$.

1980, Preliminary investigation of a shallow ground-water flow system associated with Connetquot Brook, Long Island, New York, 1980: U.S. Geological Survey Water-Resources Investgations 80-47, 37 p.

Reilly, T. E., and Harbaugh, A. W., 1980, A comparison of analog and digital modeling techniques for simulating three-dimensional ground-water flow on Long Island, New York: U.S. Geological Survey Water-Resources Investigations $80-14,40 \mathrm{p}$.

Reilly, T. E., Buxton, H. T., Franke, 0. L., and Wait, R. L., 1983, Effects of sanitary sewers on ground-water levels and streams in Nassau and Suffolk Counties, New York--Part 1, geohydrology, modeling strategy, and regional evaluation: U.S. Geological Survey Water-Resources Investigations $82-4045,45$ p.

Remsen, I., Hornberger, G. M., and Molz, F. J., 1971, Numerical methods in subsurface hydrology with an introduction to the finite-element method: New York, Wiley-Interscience, 389 p.

Reynolds, R. J., 1982, Base flow of streams on Long Island, New York: U.S. Geological Survey Water-Resources Investigations 81-48, 33 p. 


\section{REFERENCES CITED (continued)}

Segerlind, L. J., 1976, Applied finite-element analysis: New York, John Wiley, $422 \mathrm{p}$.

Suter, Russel1, delaguna, Wallace, and Perlmutter, N. M., 1949, Mapping of geologic formations and aquifers of Long Island, New York: New York State Water Power and Control Commission Bulletin GW-18, 212 p.

U.S. Geological Survey, Water resources data for New York, volume 2, Long Island: U.S. Geological Survey Water-Data Report (issued annually).

Veatch, A. C., Slichter, C. S., Bowman, Isaiah, Crosby, W. 0., and Horton, R. E., 1906, Underground water resources of Long Island, New York: U.S. Geological Survey Professional Paper 44, 394 p.

Wang, H. F., and Anderson, M. P., 1982, Introduction to ground-water modelingfinite difference and finite-element methods: San Francisco, W. H. Freeman, 237 p.

Warren, M. A., de Laguna, Wallace, and Lusczynski, N. J., 1968, Hydrology of Brookhaven National Laboratory and vicinity, Suffolk County, New York: U.S. Geological Survey Bulletin 1156-C, 127 p.

Wexler, E. J., 1987a, Ground-water flow and solute transport at a municipal landfill site on Long Island, New York--Part 1, hydrogeology and water quality: U.S. Geological Survey Water-Resources Investigations Report $86-4070,37 \mathrm{p}$.

1987b, Ground-water flow and solute transport at a municipal landfill site on Long Island, New York--Part 3, simulation of solute transport: U.S. Geological Survey Water-Resources Investigations Report 86-4207, 46 p. 
Table 9.--Description of observation wells in the study area.

[Dash indicates data unavailable]

\begin{tabular}{|c|c|c|c|c|c|c|c|c|c|c|}
\hline \multirow[b]{2}{*}{$\begin{array}{l}\text { Wel1 } \\
\text { no. } 1\end{array}$} & \multirow{2}{*}{\multicolumn{2}{|c|}{ Latitude/Longitude }} & \multirow[b]{2}{*}{$\begin{array}{l}\text { Sequence } \\
\text { number }{ }^{2}\end{array}$} & \multirow[b]{2}{*}{ owner ${ }^{3}$} & \multicolumn{2}{|c|}{$\begin{array}{c}\text { Elevation above } \\
\text { sea level }\end{array}$} & \multirow{2}{*}{$\begin{array}{l}\text { Total } \\
\text { well } \\
\text { depth } \\
\text { (ft) }\end{array}$} & \multirow{2}{*}{$\begin{array}{l}\text { Depth } \\
\text { to } \\
\text { top of } \\
\text { screen } \\
(f t)\end{array}$} & \multirow[b]{2}{*}{$\begin{array}{c}\text { Screen } \\
\text { length } \\
(\mathrm{ft})\end{array}$} & \multirow[b]{2}{*}{$\begin{array}{l}\text { We11 } \\
\text { diam. } \\
\text { (in) }\end{array}$} \\
\hline & & & & & $\begin{array}{l}\text { Measuring } \\
\text { point } \\
(\mathrm{ft})\end{array}$ & $\begin{array}{c}\text { Land } \\
\text { surf ace } \\
(\mathrm{ft})\end{array}$ & & & & \\
\hline S 3529 & 404801 & 725538 & 01 & USGS & 37.11 & 34 & 45 & 40 & 5 & 2 \\
\hline S 3530 & 404918 & 725603 & 01 & USGS & 65.92 & 66 & 45 & -- & -- & 2 \\
\hline S 3871 & 405010 & 725809 & 01 & USGS & 128.64 & 128 & 87 & -- & -- & 2 \\
\hline S 9129 & 404914 & 725317 & 01 & BNL & 35.81 & 34 & 29 & 26 & 3 & 2 \\
\hline S 9130 & 404829 & 725305 & 01 & BNL & 27.08 & 26 & 28 & 25 & 3 & 2 \\
\hline S 9135 & 404821 & 725402 & 01 & BNL & 18.63 & 18 & 8 & 5 & 3 & 1 \\
\hline S33825 & 404738 & 725654 & 01 & SCWA & 70.60 & 69 & 113 & 102 & 11 & 6 \\
\hline S43739 & 404817 & 725806 & 01 & SCDHS & 76.88 & 77 & 50 & 46 & 4 & 2 \\
\hline S43741 & 404829 & 725803 & 01 & SCDHS & 81.74 & 82 & 53 & 49 & 4 & 2 \\
\hline S43748 & 404752 & 725757 & 01 & SCDHS & 67.08 & 43 & 67 & 39 & 4 & 2 \\
\hline S43750 & 404917 & 725840 & 01 & SCDHS & 81.32 & 82 & 48 & 44 & 4 & 2 \\
\hline S44574 & 404728 & 725548 & 01 & ТОВ & -- & 69 & 52 & 49 & 2 & 2 \\
\hline S44575 & 404728 & 725548 & 02 & TOB & -- & 69 & 59 & 57 & 2 & 2 \\
\hline S44576 & 404728 & 725548 & 03 & ТОВ & 70.43 & 69 & 72 & 70 & 2 & 2 \\
\hline S44577 & 404731 & 725535 & 01 & ТОВ & 66.59 & 65 & 50 & 46 & 4 & 2 \\
\hline S44578 & 404731 & 725535 & 02 & ТОВ & 66.40 & 65 & 55 & 52 & 2 & 2 \\
\hline S44581 & 404747 & 725535 & 01 & TOB & 36.26 & 35 & 22 & 20 & 2 & 2 \\
\hline 547224 & 404817 & 725325 & 01 & SCDHS & 21.53 & 19 & 33 & 20 & 10 & 6 \\
\hline S47746 & 404848 & 725717 & 01 & SCDHS & 89.47 & 91 & 84 & 72 & 10 & 6 \\
\hline S47747 & 404740 & 725451 & 01 & SCDHS & 28.89 & 31 & 34 & 22 & 10 & 4 \\
\hline S47750 & 405004 & 725154 & 01 & SCDHS & 93.57 & 94 & 95 & 83 & 10 & 6 \\
\hline S47751 & 404607 & 725947 & 02 & SCDHS & 22.42 & 24 & 38 & 23 & 10 & 4 \\
\hline S47752 & 404607 & 725947 & 01 & SCDHS & 22.77 & 24 & 100 & 87 & 10 & 4 \\
\hline S47756 & 404922 & 725950 & 01 & SCDHS & 84.77 & 87 & 69 & 56 & 10 & 6 \\
\hline$\$ 47975$ & 405050 & 725953 & 01 & SCDHS & 149.61 & 151 & 129 & 117 & 10 & 6 \\
\hline S54883 & 405049 & 725310 & 01 & USGS & 79.43 & 80 & 66 & -- & -- & 2 \\
\hline S56746 & 404747 & 725807 & 01 & USGS & 66.20 & 64 & 87 & -- & -- & 2 \\
\hline S62404 & 405033 & 725600 & 01 & USGS & 54.67 & 52 & 45 & 41 & 4 & 2 \\
\hline S65603 & 404718 & 725749 & 01 & USGS & 53.69 & 54 & 70 & 65 & 5 & 2 \\
\hline S65858 & 405025 & 725735 & 01 & USGS & 117.18 & 118 & 95 & 91 & 4 & 2 \\
\hline S66508 & 405013 & 725640 & 01 & SCDHS & 65.47 & 66 & 62 & 54 & 5 & 4 \\
\hline S70928 & 404903 & 725502 & 01 & SCDHS & 45.55 & 45 & 18 & 16 & 2 & 2 \\
\hline 572113 & 404633 & 725755 & 01 & USGS & 33.28 & 34 & 32 & 28 & 4 & 2 \\
\hline S72114 & 404912 & 725647 & 01 & USGS & 107.81 & 108 & 91 & 87 & 4 & 2 \\
\hline s72115 & 404824 & 725641 & 01 & USGS & 86.88 & 86 & 74 & 70 & 4 & 2 \\
\hline$S 72116$ & 404754 & 725645 & 01 & USGS & 75.61 & 76 & 74 & 70 & 4 & 2 \\
\hline S72117 & 404722 & 725629 & 01 & USGS & 63.67 & 63 & 64 & 60 & 4 & 2 \\
\hline S72118 & 404646 & 725627 & 01 & USGS & 54.24 & 55 & 52 & 48 & 4 & 2 \\
\hline S72119 & 404713 & 725614 & 01 & USGS & 63.24 & 64 & 54 & 50 & 4 & 2 \\
\hline S72120 & 404640 & 725602 & 01 & USGS & 48.32 & 48 & 52 & 48 & 4 & 2 \\
\hline
\end{tabular}

1 Well numbers are assigned by New York State Department of Environmental Conservation. Prefix S designates Suffolk County.

2 Sequence numbers are assigned when two or more wells have the same latitude and longitude.

3 TOB, Town of Brookhaven; BNL, Brookhaven National Laboratory; SCWA, Suffolk County Water Authority; SCDHS, Suffolk County Department of Health Services; BFD, Brookhaven Fire Department; YFD, Yaphank Fire Department. 
Table 9.--Description of observation wells in the study area (continued)

[Dash indicates data unavailable]

\begin{tabular}{|c|c|c|c|c|c|c|c|c|c|c|}
\hline \multirow[b]{2}{*}{$\begin{array}{l}\text { We11 } \\
\text { no.1 }\end{array}$} & \multirow{2}{*}{\multicolumn{2}{|c|}{ Lat Itude/Long I tude }} & \multirow[b]{2}{*}{$\begin{array}{l}\text { Sequence } \\
\text { number }{ }^{2}\end{array}$} & \multirow[b]{2}{*}{ Owner ${ }^{3}$} & \multicolumn{2}{|c|}{$\begin{array}{c}\text { Elevation above } \\
\text { sea level }\end{array}$} & \multirow{2}{*}{$\begin{array}{l}\text { Total } \\
\text { well } \\
\text { depth } \\
(\mathrm{ft}) \\
\end{array}$} & \multirow{2}{*}{$\begin{array}{l}\text { Depth } \\
\text { to } \\
\text { top of } \\
\text { screen } \\
\text { (ft) }\end{array}$} & \multirow[b]{2}{*}{$\begin{array}{c}\text { Screen } \\
\text { length } \\
(f t)\end{array}$} & \multirow[b]{2}{*}{$\begin{array}{l}\text { Well } \\
\text { diam. } \\
\text { (in) }\end{array}$} \\
\hline & & & & & $\begin{array}{l}\text { Measuring } \\
\text { point } \\
\text { (ft) }\end{array}$ & $\begin{array}{c}\text { Land } \\
\text { surf ace } \\
(\mathrm{ft})\end{array}$ & & & & \\
\hline s72121 & 404816 & 725609 & 01 & USGS & 70.41 & 69 & 66 & 62 & 4 & 2 \\
\hline S72122 & 404742 & 725605 & 01 & USGS & 76.55 & 75 & 72 & 68 & 4 & 2 \\
\hline s72123 & 404805 & 725545 & 01 & USGS & 30.70 & 30 & 23 & 19 & 4 & 2 \\
\hline S72124 & 404805 & 725556 & 01 & USGS & 44.66 & 43 & 43 & 39 & 4 & 2 \\
\hline S72125 & 404713 & 725548 & 01 & USGS & 67.76 & 67 & 64 & 60 & 4 & 2 \\
\hline S72126 & 404700 & 725544 & 01 & USGS & 58.33 & 59 & 63 & 59 & 4 & 2 \\
\hline s72127 & 404643 & 725542 & 01 & USGS & 55.39 & 55 & 54 & 50 & 4 & 2 \\
\hline$S 72128$ & 404621 & 725540 & 01 & USGS & 47.58 & 48 & 54 & 50 & 4 & 2 \\
\hline S72129 & 404826 & 725538 & 01 & USGS & 42.96 & 42 & 44 & 40 & 4 & 2 \\
\hline S72130 & 404742 & 725525 & 01 & USGS & 27.63 & 28 & 23 & 19 & 4 & 2 \\
\hline s72131 & 404722 & 725526 & 01 & USGS & 47.82 & 47 & 55 & 51 & 4 & 2 \\
\hline$s 72132$ & 404713 & 725525 & 01 & USGS & 64.54 & 64 & 62 & 58 & 4 & 2 \\
\hline s72133 & 404653 & 725522 & 01 & USGS & 57.08 & 56 & 61 & 57 & 4 & 2 \\
\hline S72134 & 404801 & 725516 & 01 & USGS & 36.76 & 36 & 34 & 30 & 4 & 2 \\
\hline s72136 & 404734 & 725516 & 03 & USGS & 29.56 & 29 & 63 & 59 & 4 & 2 \\
\hline S72138 & 404740 & 725506 & 01 & USGS & 32.48 & 32 & 28 & 24 & 4 & 2 \\
\hline s72139 & 404849 & 725458 & 01 & USGS & 43.75 & 44 & 40 & 36 & 4 & 2 \\
\hline S72140 & 404822 & 725453 & 01 & USGS & 38.54 & 39 & 41 & 37 & 4 & 2 \\
\hline S72141 & 404801 & 725451 & 01 & USGS & 33.79 & 34 & 34 & 30 & 4 & 2 \\
\hline S72142 & 404940 & 725436 & 01 & USGS & 44.26 & 44 & 46 & 42 & 4 & 2 \\
\hline s72143 & 404754 & 725432 & 01 & USGS & 30.73 & 29 & 34 & 30 & 4 & 2 \\
\hline s72144 & 404711 & 725431 & 01 & USGS & 23.47 & 20 & 32 & 28 & 4 & 2 \\
\hline S72145 & 404719 & 725419 & 01 & USGS & 25.95 & 25 & 33 & 29 & 4 & 2 \\
\hline S72146 & 404730 & 725356 & 01 & USGS & 22.45 & 22 & 33 & 29 & 4 & 2 \\
\hline S72147 & 404756 & 725343 & 01 & USGS & 31.41 & 30 & 38 & 34 & 4 & 2 \\
\hline S72148 & 404738 & 725339 & 01 & USGS & 25.95 & 24 & 35 & 31 & 4 & 2 \\
\hline S72149 & 404704 & 725501 & 01 & BFD & 17.81 & 17 & 46 & 30 & 15 & 6 \\
\hline s72150 & 404713 & 725503 & 01 & BFD & 21.86 & 20 & 47 & 32 & 15 & 6 \\
\hline S72151 & 404708 & 725458 & 01 & BFD & 22.04 & 21 & 50 & 35 & 15 & 6 \\
\hline S72152 & 404714 & 725451 & 01 & BFD & 26.60 & 25 & 49 & 34 & 15 & 4 \\
\hline S72153 & 404726 & 725447 & 01 & BFD & 27.75 & 27 & 48 & 33 & 15 & 6 \\
\hline S72154 & 404741 & 725417 & 01 & BFD & 23.92 & 22 & 45 & 30 & 15 & -- \\
\hline S72155 & 404751 & 725409 & 01 & BFD & 23.35 & 22 & 47 & 32 & 15 & 8 \\
\hline $\mathrm{S} 72156$ & 404763 & 725253 & 01 & BFD & 16.03 & 14 & 51 & 36 & 15 & -- \\
\hline S72157 & 404749 & 725245 & 01 & BFD & 19.05 & 18 & 50 & 35 & 15 & -- \\
\hline s72158 & 404812 & 725256 & 01 & BFD & 16.22 & 15 & 45 & 30 & 15 & -- \\
\hline$s 72159$ & 404746 & 725450 & 01 & BFD & 33.01 & 32 & 51 & 36 & 15 & 6 \\
\hline s72160 & 404646 & 725457 & 01 & BFD & 10.81 & 8 & 45 & 30 & 15 & 6 \\
\hline s72161 & 404645 & 725442 & 01 & BFD & 19.38 & 18 & 42 & 27 & 15 & 4 \\
\hline S72162 & 404653 & 725426 & 01 & BFD & 13.14 & 12 & 42 & 27 & 15 & 8 \\
\hline s72163 & 404631 & 725402 & 01 & BFD & 13.70 & 12 & 42 & 27 & 15 & 4 \\
\hline S72164 & 404623 & 725359 & 01 & BFD & 10.98 & 9 & 48 & 33 & 15 & 6 \\
\hline S72165 & 404622 & 725409 & 01 & BFD & 12.79 & 11 & 45 & 30 & 15 & 8 \\
\hline S72167 & 404624 & 725430 & 01 & BFD & 15.81 & 15 & 45 & 30 & 15 & 8 \\
\hline s72168 & 404605 & 725433 & 01 & BFD & 10.45 & 9 & 45 & 30 & 15 & 4 \\
\hline
\end{tabular}


Table 9.--Description of observation wells in the study area (continued)

[Dash Indicates data unavailable]

\begin{tabular}{|c|c|c|c|c|c|c|c|c|c|c|}
\hline \multirow[b]{2}{*}{$\begin{array}{l}\text { Well } \\
\text { no.1 }\end{array}$} & \multirow{2}{*}{\multicolumn{2}{|c|}{ Lat itude/Long itude }} & \multirow[b]{2}{*}{$\begin{array}{l}\text { Sequence } \\
\text { number }{ }^{2}\end{array}$} & \multirow[b]{2}{*}{ Owner ${ }^{3}$} & \multicolumn{2}{|c|}{$\begin{array}{c}\text { Elevation above } \\
\text { sea level }\end{array}$} & \multirow{2}{*}{$\begin{array}{l}\text { Total } \\
\text { well } \\
\text { depth } \\
\text { (ft) }\end{array}$} & \multirow{2}{*}{$\begin{array}{c}\text { Depth } \\
\text { to } \\
\text { top of } \\
\text { screen } \\
\text { (ft) }\end{array}$} & \multirow[b]{2}{*}{$\begin{array}{c}\text { Screen } \\
\text { length } \\
(\mathrm{ft})\end{array}$} & \multirow[b]{2}{*}{$\begin{array}{l}\text { We } 11 \\
\text { diam. } \\
\text { (in) }\end{array}$} \\
\hline & & & & & $\begin{array}{c}\text { Measuring } \\
\text { point } \\
(\mathrm{ft})\end{array}$ & $\begin{array}{c}\text { Land } \\
\text { surf ace } \\
(f t)\end{array}$ & & & & \\
\hline$S 72169$ & 404631 & 725444 & 01 & BFD & 18.84 & 16 & 46 & 31 & 15 & 4 \\
\hline$s 72170$ & 404627 & 725452 & 01 & BFD & 12.94 & 12 & 33 & 18 & 15 & 4 \\
\hline$S 72171$ & 404608 & 725448 & 01 & BFD & 8.90 & 7 & 46 & 31 & 15 & 4 \\
\hline s72172 & 404552 & 725456 & 01 & BED & 6.79 & 5 & 42 & 27 & 15 & 4 \\
\hline$S 72173$ & 404603 & 725454 & 01 & BFD & 8.76 & 7 & 41 & 26 & 15 & 6 \\
\hline S72174 & 404623 & 725517 & 01 & BFD & 18.13 & 17 & 44 & 29 & 15 & 6 \\
\hline 572175 & 404557 & 725533 & 01 & BFD & 19.16 & 18 & 45 & 30 & 15 & 6 \\
\hline S72176 & 404956 & 725405 & 01 & BFD & 31.61 & 30 & -- & -- & 15 & 4 \\
\hline s72177 & 405023 & 725548 & 01 & YFD & 47.60 & 45 & 53 & 38 & 15 & 4 \\
\hline$S 72812 M$ & 404802 & 725538 & 01 & USGS & 36.20 & 36 & 198 & 189 & 5 & 4 \\
\hline$S 72813 M$ & 404732 & 725544 & 05 & USGS & 72.91 & 69 & 219 & 210 & 5 & 4 \\
\hline S72814M & 404653 & 725522 & 02 & USGS & 56.03 & 56 & 178 & 170 & 5 & 4 \\
\hline S72815 & 404753 & 725606 & 01 & USGS & 78.81 & 78 & 66 & 62 & 4 & 4 \\
\hline$S 72816$ & 404801 & 725607 & 01 & USGS & 78.01 & 79 & 67 & 63 & 4 & 2 \\
\hline 572817 & 404740 & 725530 & 01 & USGS & 30.25 & 29 & 22 & 18 & 4 & 2 \\
\hline 572818 & 404736 & 725525 & 01 & USGS & 23.58 & 23 & 8 & 4 & 4 & 2 \\
\hline 572819 & 404736 & 725525 & 02 & USGS & 23.95 & 23 & 23 & 19 & 4 & 2 \\
\hline S72820 & 404736 & 725525 & 03 & USGS & 23.97 & 23 & 43 & 39 & 4 & 2 \\
\hline S72821 & 404734 & 725516 & 01 & USGS & 29.01 & 29 & 23 & 19 & 4 & 2 \\
\hline S72822 & 404734 & 725516 & 02 & USGS & 28.75 & 29 & 43 & 39 & 4 & 2 \\
\hline$S 72823$ & 404727 & 725521 & 01 & USGS & 21.96 & 21 & 13 & 9 & 4 & 2 \\
\hline 572824 & 404727 & 725521 & 02 & USGS & 21.65 & 21 & 34 & 30 & 4 & 2 \\
\hline$S 72825$ & 404726 & 725512 & 01 & USGS & 0.00 & 21 & 24 & 20 & 4 & 2 \\
\hline$S 72826$ & 404726 & 725512 & 02 & USGS & 21.43 & 21 & 43 & 39 & 4 & 2 \\
\hline S72827 & 404720 & 725506 & 01 & USGS & 20.09 & 21 & 14 & 10 & 4 & 2 \\
\hline S72828 & 404720 & 725506 & 02 & USGS & 20.00 & 21 & 33 & 29 & 4 & 2 \\
\hline$S 72829$ & 404659 & 725509 & 01 & USGS & 34.22 & 33 & 33 & 29 & 4 & 2 \\
\hline 572830 & 404651 & 725533 & 01 & USGS & 59.60 & 59 & 53 & 49 & 4 & 2 \\
\hline S72831 & 404703 & 725524 & 01 & USGS & 61.10 & 61 & 56 & 52 & 4 & 2 \\
\hline$S 72832$ & 404717 & 725526 & 01 & USGS & 54.25 & 54 & 72 & 68 & 4 & 2 \\
\hline 572833 & 404722 & 725526 & 02 & USGS & 46.13 & 47 & 72 & 68 & 4 & 2 \\
\hline S72834 & 404730 & 725530 & 01 & USGS & 40.14 & 39 & 34 & 30 & 4 & 2 \\
\hline 572835 & 404728 & 725536 & 01 & USGS & 54.88 & 54 & 64 & 60 & 4 & 2 \\
\hline$\$ 72836$ & 404726 & 725543 & 01 & USGS & 62.75 & 62 & 54 & 50 & 4 & 2 \\
\hline 572837 & 404726 & 725543 & 02 & USGS & 62.95 & 62 & 73 & 69 & 4 & 2 \\
\hline 572838 & 404724 & 725548 & 01 & USGS & 66.78 & 66 & 64 & 60 & 4 & 2 \\
\hline s73750 & 404742 & 725535 & 01 & USGS & 38.27 & 36 & 34 & 29 & 5 & 4 \\
\hline S73751 & 404742 & 725535 & 02 & USGS & 38.39 & 36 & 55 & 50 & 5 & 4 \\
\hline s73752 & 404742 & 725535 & 03 & USGS & 39.28 & 36 & 85 & 80 & 5 & 4 \\
\hline s73753 & 404738 & 725535 & 01 & USGS & 38.60 & 37 & 34 & 29 & 5 & 4 \\
\hline
\end{tabular}

1 Well numbers are assigned by New York State Department of Environmental Conservation. Prefix S designates Suffolk County; suffix M designates wells screned in Magothy aquifer.

2 Sequence numbers are assigned when two or more wells have the same latitude and longitude.

3 TOB, Town of Brookhaven; BNL, Brookhaven National Laboratory; SCWA, Suffolk County Water Authority; SCDHS, Suffolk County Department of Health Services; BFD, Brookhaven Fire Department; YFD, Yaphank Fire Department. 
Table 9.--Description of observation wells in the study area (continued)

[Dash 1nd1cates data unava1lable]

\begin{tabular}{|c|c|c|c|c|c|c|c|c|c|c|}
\hline \multirow[b]{2}{*}{$\begin{array}{l}\text { Well } \\
\text { no. } 1\end{array}$} & \multirow{2}{*}{\multicolumn{2}{|c|}{ Lat 1 tude/Long 1 tude }} & \multirow[b]{2}{*}{$\begin{array}{l}\text { Sequence } \\
\text { number }{ }^{2}\end{array}$} & \multirow[b]{2}{*}{ Owner ${ }^{3}$} & \multicolumn{2}{|c|}{$\begin{array}{c}\text { Elevation above } \\
\text { sea level }\end{array}$} & \multirow{2}{*}{$\begin{array}{l}\text { Total } \\
\text { well } \\
\text { depth } \\
(\mathrm{ft}) \\
\end{array}$} & \multirow{2}{*}{$\begin{array}{c}\text { Depth } \\
\text { to } \\
\text { top of } \\
\text { screen } \\
(f t)\end{array}$} & \multirow[b]{2}{*}{$\begin{array}{c}\text { Screen } \\
\text { length } \\
(\mathrm{ft})\end{array}$} & \multirow[b]{2}{*}{$\begin{array}{l}\text { We } 11 \\
\mathrm{~d} 1 \mathrm{am} . \\
(1 \mathrm{n})\end{array}$} \\
\hline & & & & & $\begin{array}{l}\text { Measuring } \\
\text { point } \\
(\mathrm{ft})\end{array}$ & $\begin{array}{c}\text { Land } \\
\text { surface } \\
(f t)\end{array}$ & & & & \\
\hline s73754 & 404738 & 725535 & 02 & TOB & 38.67 & 37 & 54 & 49 & 5 & 4 \\
\hline$\$ 73755$ & 404738 & 725535 & 03 & TOB & 39.79 & 37 & 85 & 80 & 5 & 4 \\
\hline 573756 & 404734 & 725537 & 03 & TOB & 58.11 & 55 & 103 & 98 & 5 & 4 \\
\hline 573757 & 404734 & 725537 & 02 & TOB & 57.35 & 55 & 73 & 68 & 5 & 4 \\
\hline s73758 & 404734 & 725537 & 01 & TOB & 57.38 & 55 & 53 & 48 & 5 & 4 \\
\hline s73759 & 404734 & 725537 & 04 & TOB & 57.59 & 55 & 128 & 123 & 5 & 4 \\
\hline 573760 & 404732 & 725544 & 01 & TOB & 71.74 & 69 & 65 & 60 & 5 & 4 \\
\hline S73761 & 404732 & 725544 & 02 & TOB & 71.35 & 69 & 85 & 80 & 5 & 4 \\
\hline 573762 & 404732 & 725544 & 03 & TOB & 71.89 & 69 & 115 & 110 & 5 & 4 \\
\hline 573763 & 404732 & 725544 & 04 & TOB & 72.17 & 69 & 140 & 135 & 5 & 4 \\
\hline S73764 & 404730 & 725549 & 01 & TOB & 71.49 & 69 & 58 & 53 & 5 & 4 \\
\hline S73765 & 404730 & 725549 & 02 & TOB & $72: 02$ & 69 & 78 & 73 & 5 & 4 \\
\hline s73766 & 404730 & 725549 & 03 & TOB & 72.41 & 69 & 108 & 103 & 5 & 4 \\
\hline S73767 & 404729 & 725553 & 01 & TOB & 72.80 & 69 & 63 & 58 & 5 & 4 \\
\hline S73768 & 404729 & 725553 & 02 & TOB & 72.67 & 69 & 79 & 74 & 5 & 4 \\
\hline s73769 & 404753 & 725606 & 02 & тов & 80.13 & 78 & 82 & 77 & 5 & 4 \\
\hline s73770 & 404749 & 725543 & 01 & TOB & 42.73 & 42 & 28 & 23 & 5 & 4 \\
\hline S73943 & 404740 & 725530 & 02 & TOB & -- & 29 & 45 & 43 & 2 & 1 \\
\hline S73944 & 404740 & 725530 & 03 & TOB & -- & 29 & 65 & 63 & 2 & 1 \\
\hline S73945 & 404730 & 725530 & 02 & TOB & 40.03 & 39 & 50 & 48 & 2 & 1 \\
\hline 573946 & 404733 & 725524 & 01 & TOB & 24.65 & 23 & 42 & 40 & 2 & 1 \\
\hline S73947 & 404733 & 725524 & 02 & TOB & 24.62 & 23 & 60 & 58 & 2 & 1 \\
\hline S7 3948 & 404726 & 725514 & 01 & TOB & 20.18 & 19 & 37 & 35 & 2 & 1 \\
\hline$\$ 73949$ & 404939 & 725450 & 01 & SCDHS & 53.06 & 51 & 32 & -- & - & 2 \\
\hline S73951 & 404835 & 725334 & 01 & USGS & 29.30 & 28 & 31 & -- & -- & 1 \\
\hline S73952 & 404922 & 725355 & 01 & USGS & 38.21 & 35 & -- & -- & -- & 2 \\
\hline S73953 & 404728 & 725509 & 01 & USGS & 22.49 & 22 & 44 & 40 & 4 & 2 \\
\hline S73954 & 404728 & 725509 & 02 & USGS & 22.84 & 22 & 64 & 60 & 4 & 2 \\
\hline S73955 & 404720 & 725506 & 03 & USGS & -- & 21 & 63 & 59 & 4 & 1 \\
\hline S74765 & 404843 & 725941 & 01 & TOB & 84.54 & 85 & 59 & 55 & 4 & 2 \\
\hline 574766 & 404807 & 725938 & 01 & TOB & 62.05 & 63 & -- & -- & 4 & 2 \\
\hline 574767 & 404944 & 725858 & 01 & TOB & 100.68 & 101 & 68 & 64 & 4 & 2 \\
\hline S74768 & 404716 & 725857 & 01 & TOB & 47.79 & 47 & -- & -- & 4 & 2 \\
\hline 574769 & 404551 & 725749 & 01 & тов & 26.98 & 27 & 25 & 21 & 4 & 2 \\
\hline 574770 & 404710 & 725702 & 01 & TOB & 60.54 & 61 & 34 & 30 & 4 & 2 \\
\hline 574771 & 404611 & 725653 & 01 & TOB & 38.28 & 38 & 35 & 31 & 4 & 2 \\
\hline S74772 & 405038 & 725705 & 01 & TOB & 79.10 & 78 & 51 & 47 & 4 & 2 \\
\hline 574773 & 404956 & 725528 & 01 & TOB & 58.16 & 58 & 44 & 40 & 4 & 2 \\
\hline S74774 & 404734 & 725431 & 01 & TOB & 27.32 & 23 & 28 & 24 & 4 & 2 \\
\hline
\end{tabular}

